Article

\title{
Vertical Stratification of Beetles in Deciduous Forest Communities in the Centre of European Russia
}

\author{
Alexander B. Ruchin $1, * \mathbb{1}$ and Leonid V. Egorov ${ }^{1,2}$ \\ 1 Joint Directorate of the Mordovia State Nature Reserve and National Park "Smolny", 430005 Saransk, Russia; \\ platyscelis@mail.ru \\ 2 Prisursky State Nature Reserve, 428034 Cheboksary, Russia \\ * Correspondence: ruchin.alexander@gmail.com
}

Citation: Ruchin, A.B.; Egorov, L.V. Vertical Stratification of Beetles in Deciduous Forest Communities in the Centre of European Russia. Diversity 2021, 13, 508. https://doi.org/ $10.3390 / \mathrm{d} 13110508$

Academic Editor: Tibor Magura

Received: 5 October 2021

Accepted: 19 October 2021

Published: 20 October 202

Publisher's Note: MDPI stays neutral with regard to jurisdictional claims in published maps and institutional affiliations.

Copyright: (c) 2021 by the authors. Licensee MDPI, Basel, Switzerland. This article is an open access article distributed under the terms and conditions of the Creative Commons Attribution (CC BY) license (https:// creativecommons.org/licenses/by/ $4.0 /)$.
Abstract: Studies on the vertical distribution of arthropods in temperate forests have revealed the uneven vertical distribution of communities. Many factors influence these patterns simultaneously. However, there are still many questions related to the vertical distribution of Coleoptera in deciduous forests of the temperate zone. The research was carried out within the territory of the Republic of Mordovia (the center of the European part of Russia). Fermental traps with a bait made of fermenting beer with sugar were used to collect Coleoptera. The collections were carried out from May to September 2020 at five sites in a deciduous forest. We set traps at a height of 1.5, 3.5, 7.5 and $12 \mathrm{~m}$ above the ground) on the branches of trees. Ninety-two species were identified at the end of studies at different heights. The families Nitidulidae (15 species), Cerambycidae (14 species), Elateridae (7 species), Curculionidae (7 species) and Scarabaeidae (7 species) had the greatest species diversity. The greatest species diversity was recorded at a height of $1.5 \mathrm{~m}$, while the smallest one was recorded at a height of $7.5 \mathrm{~m}$. The minimum number of specimens was recorded at a height of $12 \mathrm{~m}$. The largest differences in the Jaccard similarity index were obtained between samples from a height of 1.5 and $12 \mathrm{~m}$. The Shannon's diversity index was higher near the ground than in the tree crowns (at heights of 7.5 and $12 \mathrm{~m}$ ), and the Simpson index had the opposite tendency. Glischrochilus hortensis and to a lesser extent Cychramus luteus preferred to live in the lowest layers of deciduous forest $(1.5 \mathrm{~m})$. Cryptarcha strigata was mainly found with relatively high numbers at heights of $3.5 \mathrm{~m}$ and $7.5 \mathrm{~m}$. The abundance and occurrence of Protaetia marmorata and Quedius dilatatus were higher in the uppermost layers of the crowns. The number of saproxylic beetle species at heights of 3.5-12 $\mathrm{m}$ was almost the same, while in the surface layer it decreased. The number of anthophilic beetle species was also lower at a low altitude. Our data confirm the relevance of sampling in forest ecosystems at different altitudes while studying arthropod biodiversity.

Keywords: insects; number of species; beer trap; saproxylic beetles; Mordovia State Nature Reserve

\section{Introduction}

Forests are three-dimensional ecosystems where all organisms are distributed not only along various horizontal ecological gradients, e.g., [1-3], but also along the vertical gradient between forest litter and tree crowns [4]. For example, many studies have been conducted on the vertical stratification of different insect orders. They revealed certain patterns in their preferences in forest ecosystems, including Lepidoptera [5-7], Hymenoptera [8-11], Neuroptera [12,13], Diptera [14-16], and others [17,18].

There are certain results on vertical stratification of Coleoptera as well. Some Scolytinae species were associated with traps exposed at a height of 7 to $21 \mathrm{~m}$, while other species were associated with a height of $1.2 \mathrm{~m}$ [19]. The vertical stratification of Chrysomelidae was more evident in wet habitats than in dry ones [20]. The distribution of cerambycid beetles also slightly depends on heights [21]. Cerambycidae diversity in Canadian forests was higher in canopy than in undergrowth, whereas abundance was higher in undergrowth 
than in canopy [22]. The abundance, species richness and biomass of Cetoniinae were higher in traps set at an height of $10.5 \mathrm{~m}$. The species richness and abundance of Rutelinae is higher at an height of 4.5, 7.5 and $10.5 \mathrm{~m}$ [23]. Saproxylic Coleoptera in the canopy of deciduous forest in the Czech Republic outnumbered the undergrowth [24]. Studies in lowland tropical rainforest in North Queensland, Australia have shown that rare species occur most of the forest, unlike undergrowth [25]. In temperate deciduous forests of Japan, abundance Coleoptera was more in the canopy than in undergrowth [26]. A higher abundance and species richness of Coleoptera was observed in the understory of beech-fir and oak forests in France [27].

The use of various types of traps can influence the results of studies [28-31]. However, the use of traps with various baits and attractants and traps without baits give similar results. For example, when using traps with $\alpha$-pinene, ethanol, ipsdienol, and ipsenol, it turned out that species richness, species diversity, abundance, number of unique species of Coleoptera were higher in the undergrowth compared to traps under the canopy [32]. The average catch of Dicerca divaricata in traps with sex attractants was significantly lower in the undergrowth than in any other trap locations [33]. Catches of Monochamus galloprovincialis in traps with various attractants located in tree crowns were significantly larger than in traps located at lower forest strata [34]. The height of traps with different types of baits significantly affected the catches of some Cerambycidae and Scolytinae species. Some of them were caught more often in the canopy, and others-in the undergrowth. Touroult and Dalens [35] studied longhorn and scarab beetles using baited air traps suspended at three different heights: 3-5 m (undergrowth), 10-15 $\mathrm{m}$ and 25-30 $\mathrm{m}$ (under canopy). It turned out that for longhorn beetles, the abundance was greater in the undergrowth, but the diversity was much higher in the canopy. For scarab beetles, abundance and diversity were the same in three layers. Using green and purple multiple-funnel traps baited with ethanol or ethanol + hardwood beetle pheromone blend, Rassati et al. [36] revealed that Cerambycinae and certain species of Laminae preferred the canopy, whereas no such pattern was found in Lepturinae (Cerambycidae) species. When using traps with baits located at heights of 0.2-0.3 m and 18-23 m, Miller et al. [37] found certain preferences for many Coleoptera species. However, it did not apply to all studied species. In our research, we used fermental traps to study the vertical stratification of Coleoptera.

\section{Materials and Methods}

\subsection{Study Area}

All studies were conducted in the Republic of Mordovia (Temnikov district, Mordovia State Nature Reserve) (Figures 1 and 2). Mordovia State Nature Reserve is located on the right bank of the Moksha River and covers an area of $321.62 \mathrm{~km}^{2}$. According to the natural zoning, the protected area is included in the zone of coniferous-deciduous forests on the border with the forest-steppe. Forest communities occupy $89.3 \%$ of the entire protected area, representing the largest refugiums for threatened invertebrate species [38,39].

Pinus sylvestris (hereafter-pine) is the main species forming forests. Betula pendula (hereafter-birch) has the second rank in the forest-covering area. Tilia cordata (hereafterlinden) forests are situated at the north of the Protected Area. Quercus robur (hereafteroak) forests cover small areas in the western part of the Mordovia State Nature Reserve. Picea abies (hereafter-spruce) forests are situated mainly in floodplains of rivers and streams by covering a relatively small area [40]. Forests damaged by wildfire in 2010 are dominated by young small-leaved deciduous trees (Betula pendula, and rarer Populus tremula, and Alnus glutinosa [41].

The field survey has been carried out in the deciduous forest, consisted of Tilia cordata (90\% of the forest canopy layer) and Quercus robur (10\%) with the projective cover of $60 \%$. Understory layer (projective cover: $70 \%$ ) is represented by Acer platanoides (Aceraceae) (projective cover: 65\%), Ulmus glabra (Ulmaceae) (10\%), Tilia cordata (Malvaceae) (40\%), Euonymus verrucosus (Celastraceae) (solitary plants). Ground layer (projective cover: 85\%) consists of Carex pilosa (Cyperaceae) (projective cover: 70\%), Mercurialis perennis (Euphor- 
biaceae) (5\%), Glechoma hederacea (Lamiaceae) (2\%), Asarum europaeum (Aristolochiaceae) $(1 \%)$. Other species have projective cover of less than 1\%: Aegopodium podagraria (Apiaceae), Milium effusum (Poaceae), Stachys sylvatica (Lamiaceae), Aconitum septentrionalis (Ranunculaceae), Viola mirabilis (Violaceae), Polygonatum multiflorum (Liliaceae), Pulmonaria obscura (Boraginaceae), Geum urbanum (Rosaceae), Lathyrus vernus (Fabaceae), Rabelera holostea (Caryophyllaceae), Rubus saxatilis (Rosaceae), Equisetum sylvaticus (Equisetaceae), Dryopteris filix-mas (Dryopteridaceae), Paris quadrifolia (Liliaceae), Galium odoratum (Rubiaceae), Anthriscus sylvestris (Apiaceae).

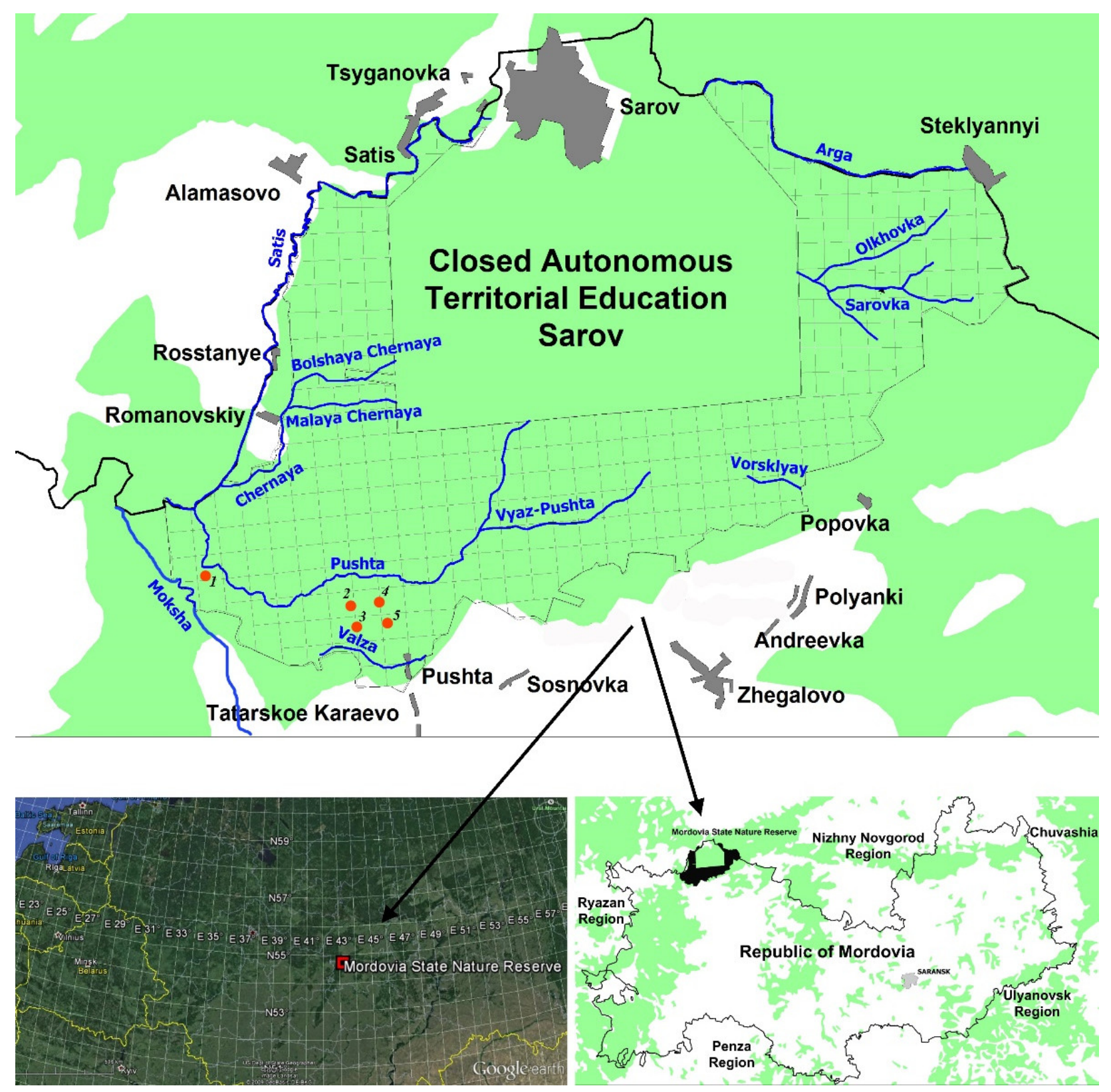

Figure 1. Geographical position of the Mordovia State Nature Reserve in Europe. The places of collection of the material (the studied areas) are indicated by numbers. 

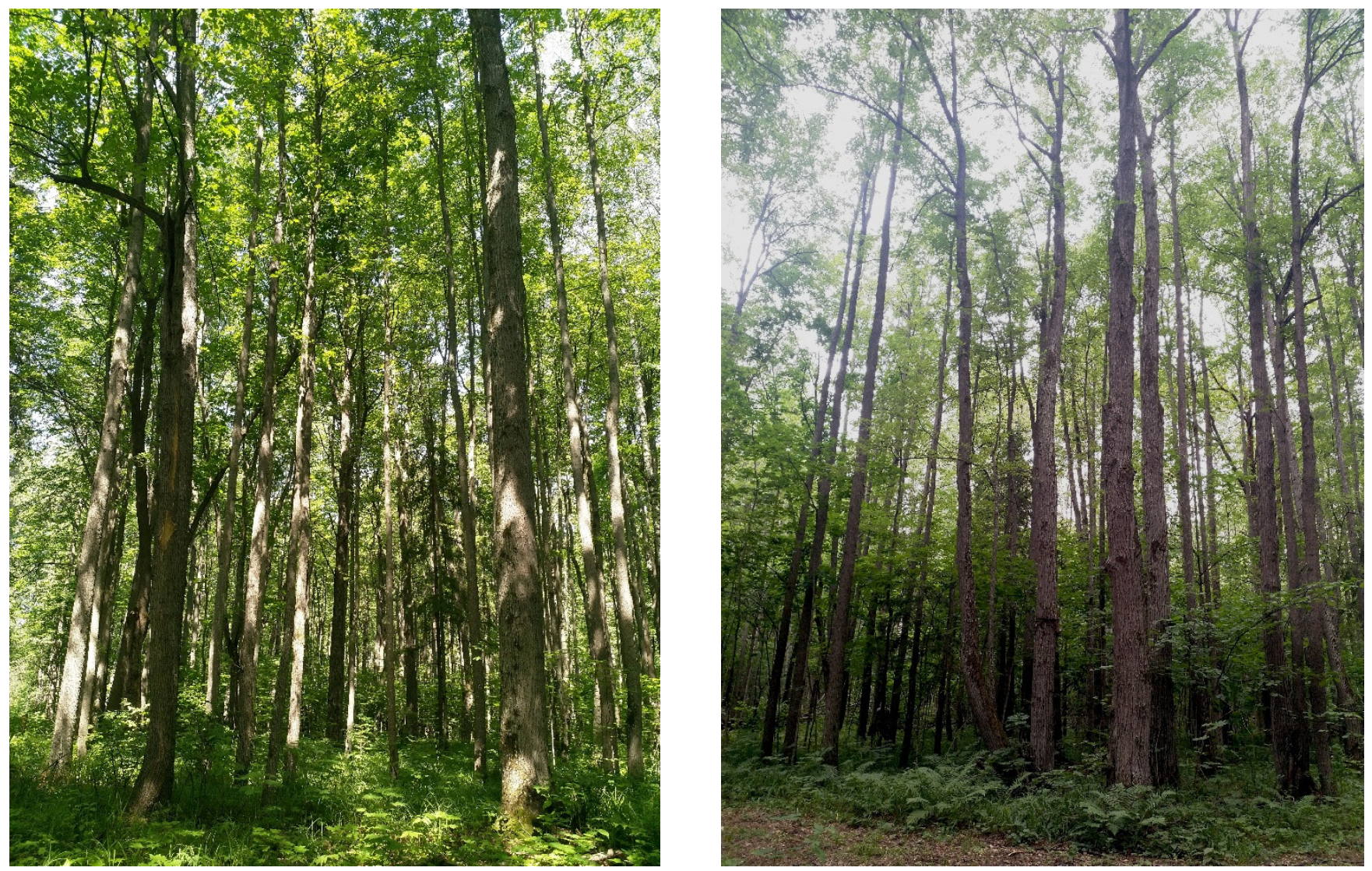

Figure 2. Research sites on the territory of the Mordovia State Nature Reserve. On the left is number 3, on the right is number 5 (the site numbers are shown in Figure 1).

\subsection{Sampling Procedures}

Coleoptera was collected from May to September 2020 in the spring-autumn period, when the activity of insects was the highest. All the places where the material was collected were solid forests. There were five such parts of deciduous forest in total. Each fragment of the forest was located more than $1.5 \mathrm{~km}$ from each other and was independent of the other fragment under study (replicate). This distance between points is an attempt to ensure non-dependence between samples; i.e., these areas were separate forest parts. Therefore, the sampling points were considered as replicates $(n=5)$.

Each sampling point had a set of four traps installed at different heights $(1.5,3.5,7.5$ and $12 \mathrm{~m}$ above the ground) on the branches of trees. We chose this height difference in order to facilitate and optimize the manual installation of traps without the need to climb trees or use special techniques and/or equipment. To avoid a possible edge effect, traps were installed inside forest areas. The total sampling effort was 172 trap exposures. There were nine replicates at each height (there were seven repetitions in one locality). 144 expositions were made in four collection localities (nine replicates at four heights), 28 expositions were made in one locality (seven replicates at four heights).

All collections were carried out using traps of our own design. A five-liter plastic container with a window cut out on one side at a distance of $10 \mathrm{~cm}$ from the bottom was used as a trap [42]. Beer was used as bait. Sugar was added to it for fermentation.

The collected samples were delivered in plastic bags containing 70\% alcohol from the forest to the laboratory, then sorted and conserved in alcohol.

\subsection{Identification and Taxonomic Position of Samples}

The classification of the family-group taxa used in this checklist follows predominantly Bouchard et al. [43]) with subsequent additions [44]. Changes for Coleoptera have been 
taken into account from the Catalog of Palaearctic [45-51], as well as for Cucujoidea from the publication of Robertson et al. [52] and for Curculionoidea from the publication of Alonso-Zarazaga et al. [53]. To clarify the nomenclature, the cited works were used, as well as the Catalog of Palaearctic Coleoptera [54,55]. The years of description of some species are specified according to Bousquet [56]. The species identification was carried out by L.V. Egorov. The samples are kept in the collection of the Mordovia State Nature Reserve (Pushta, Russia).

\subsection{Data Analyses}

When analyzing the results, we used only data on the quantitative parameter (number) of all Coleoptera individuals in traps for exposure time. Exposure time is the period between hanging a trap and taking samples for analysis (expressed in days). Mean number (M, expressed in \%) was calculated based on the exposures of all traps at given height. Occurrence is the ratio of the number of samples in which a species (taxonomic group) is present to the total number of samples (expressed in \%). Saproxylic species were determined taking into account the approaches adopted by a number of authors [57-59]. The anthophilic species were classified according to our own long-term observations.

To compare species similarity between study plots we used Jaccard index. We did not take into account insects, which were not identified to species level. Based on the collected data, we calculated widely used biodiversity indices, namely the Shannon's Diversity Index and the Simpson's diversity index [60,61].

Statistical analyses were carried out using PAST 4.07. The ordination techniques, using the principal component analysis (PCA), defined the major gradients in the spatial arrangement of the studied species selected for the analysis. For ecological interpretation of the ordination axes, groups of the height of bait trap positions were plotted onto the PCA ordination diagram as supplementary environmental data. We analyzed the species, which were represented at least 30 individuals during the sampling period.

\section{Results}

As a result of processing the material, 92 species from 26 Coleoptera families (Table A1) were identified. A total of 7882 individuals have been studied. Some specimens from the families Staphylinidae, Nitidulidae, Ptinidae, and Buprestidae could not be identified to species. Such families as Nitidulidae (15 species), Cerambycidae (14 species), Elateridae (7 species), Curculionidae (7 species) and Scarabaeidae (7 species) had the greatest species diversity (Figures 3 and 4). Representatives of these five families and the family Staphylinidae made up a total of $91.1 \%$ of all studied specimens.

Cryptarcha strigata (Fabricius, 1787) (a total of 3315 individuals), Glischrochilus hortensis (Geoffroy, 1785) (891 individuals), Protaetia marmorata (Fabricus, 1792) (821 individuals), Quedius dilatatus (Fabricius, 1787) (643 individuals), Cychramus luteus (Fabricius, 1787) (452 individuals), Soronia grisea (Linnaeus, 1758) (361 individuals), and Glischrochilus grandis (Tournier, 1872) (194 individuals) had the greatest numbers in beer traps.

The following 15 species were found at all studied heights (Dendroxena quadrimaculata (Scopoli, 1771), Quedius dilatatus, Protaetia marmorata, Cantharis nigricans O.F. Müller, 1776, Cryptarcha strigata, Cryptarcha undata (G.-A. Olivier, 1790), Cychramus luteus, Glischrochilus grandis, Glischrochilus hortensis, Glischrochilus quadripunctatus (Linnaeus, 1758), Soronia grisea, Dinoptera collaris (Linnaeus, 1758), Leptura quadrifasciata Linnaeus, 1758, Leptura thoracica (Creutzer, 1799), Rhagium mordax (De Geer, 1775), Anisandrus dispar (Fabricius, 1792)).

The greatest species diversity (58 species) was recorded at a height of $1.5 \mathrm{~m}$, the smallest one (40 species) — at of $7.5 \mathrm{~m}$ (Table A1). According to the average number of specimens, the highest numbers were obtained at heights of 1.5 and $3.5 \mathrm{~m}$ (on average of sampling point, 427 and 428 specimens, respectively). The minimum number of specimens was caught at a height of $12 \mathrm{~m}$. The relative number of saproxylic beetle species was lower at low altitude, whereas at other altitudes it increased slightly. At heights of 3.5-12 m, the number of saproxylic species was almost the same (Table A1). The relative number of 
anthophilic species was also lower at low altitude. However, at other heights it sharply increased (Table A1).

\section{Species richness}

50

40

30

20

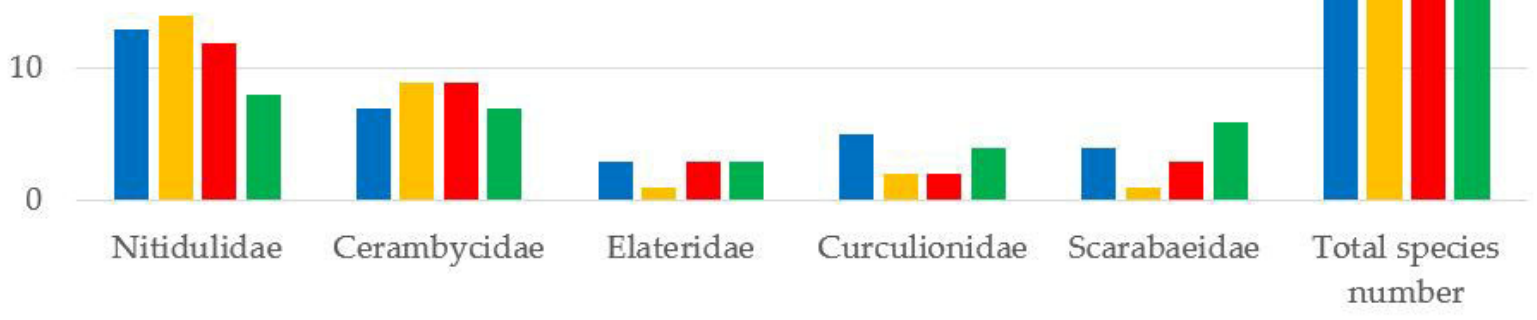

$\square 1.5 \mathrm{~m} \quad 3.5 \mathrm{~m} \quad \mathbf{m} \mathrm{m} \quad 12 \mathrm{~m}$

Figure 3. The number of species from the five Coleoptera families collected using beer traps at different heights.

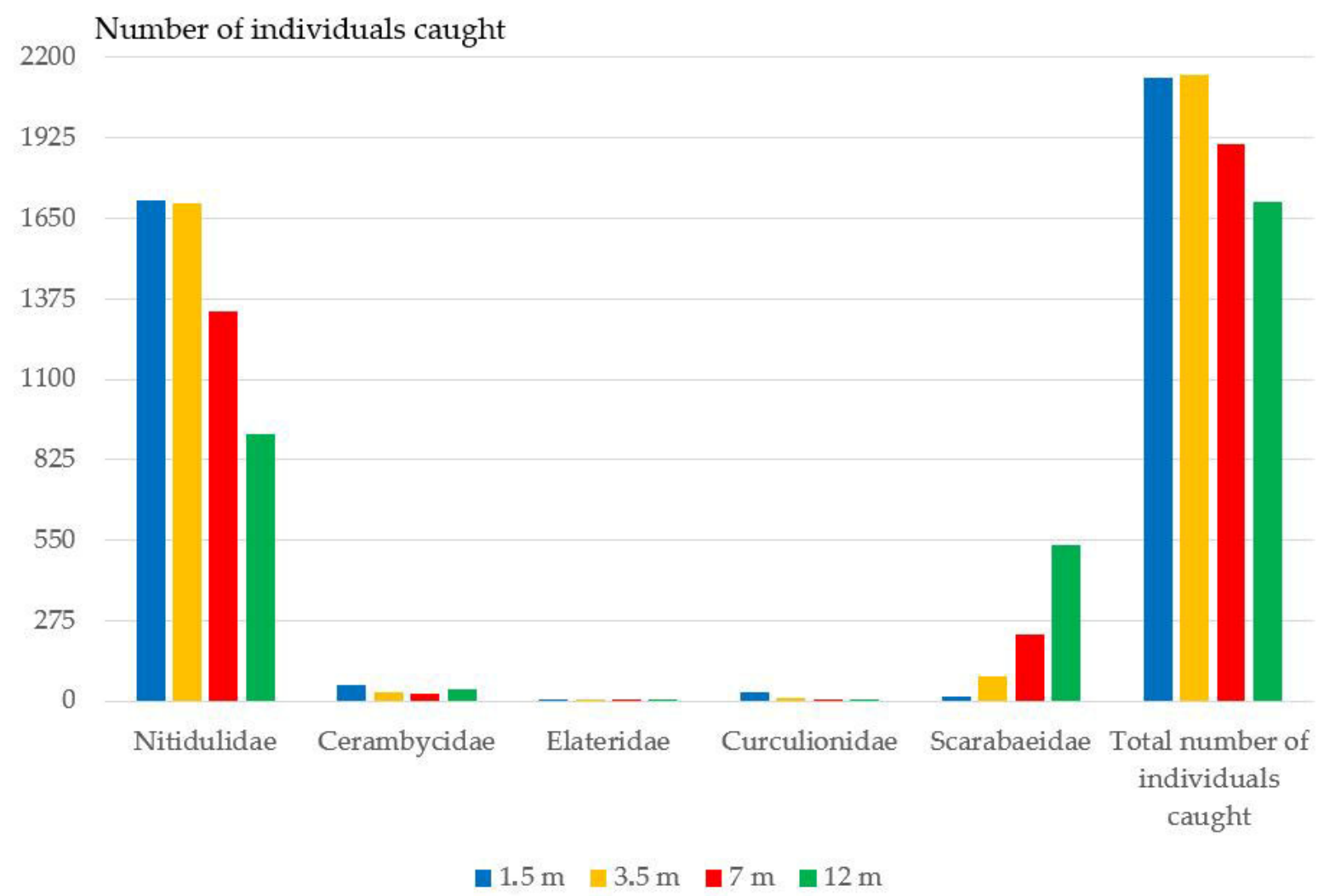

Figure 4. The number of individuals caught from five families collected using the bait traps at various height levels. 
The calculated Shannon's and Simpson's diversity indices showed the following results. The maximum values of the Shannon's diversity index and the minimum values of the Simpson's diversity index are typical for a height of $1.5 \mathrm{~m}$. Conversely, the minimum values of the Shannon's diversity index and the maximum values of the Simpson's diversity index are calculated for a height of $7.5 \mathrm{~m}$. At other heights, intermediate values between these indicators were obtained (Table 1 ).

Table 1. The main indicators of Coleoptera individuals collected using beer traps at different heights.

\begin{tabular}{|c|c|c|c|c|}
\hline Indicators & $1.5 \mathrm{~m}$ & $3.5 \mathrm{~m}$ & $7.5 \mathrm{~m}$ & $12 \mathrm{~m}$ \\
\hline Total of individuals & 2133 & 2140 & 1904 & 1705 \\
\hline Mean number of individuals & 427 & 428 & 381 & 341 \\
\hline Number of species (excluding unidentified ones) & 58 & 43 & 40 & 44 \\
\hline $\begin{array}{c}\text { Number of saproxylic species (\% of the total number of } \\
\text { species at this height) }\end{array}$ & 70.7 & 81.4 & 77.5 & 81.8 \\
\hline $\begin{array}{c}\text { Number of anthophilic species (\% of the total number of } \\
\text { species at this height) }\end{array}$ & 29.3 & 44.1 & 45.0 & 45.5 \\
\hline Shannon index & 2.14 & 1.74 & 1.63 & 1.76 \\
\hline Simpson index & 0.21 & 0.31 & 0.34 & 0.27 \\
\hline
\end{tabular}

The calculation of the Jaccard similarity index revealed that there were certain differences among the heights at which Coleoptera were recorded (Figure 5). The greatest differences were obtained between samples from a height of 1.5 and $12 \mathrm{~m}$. At the same time, the differences between the heights of 3.5 and $7.5 \mathrm{~m}$ were minimal.

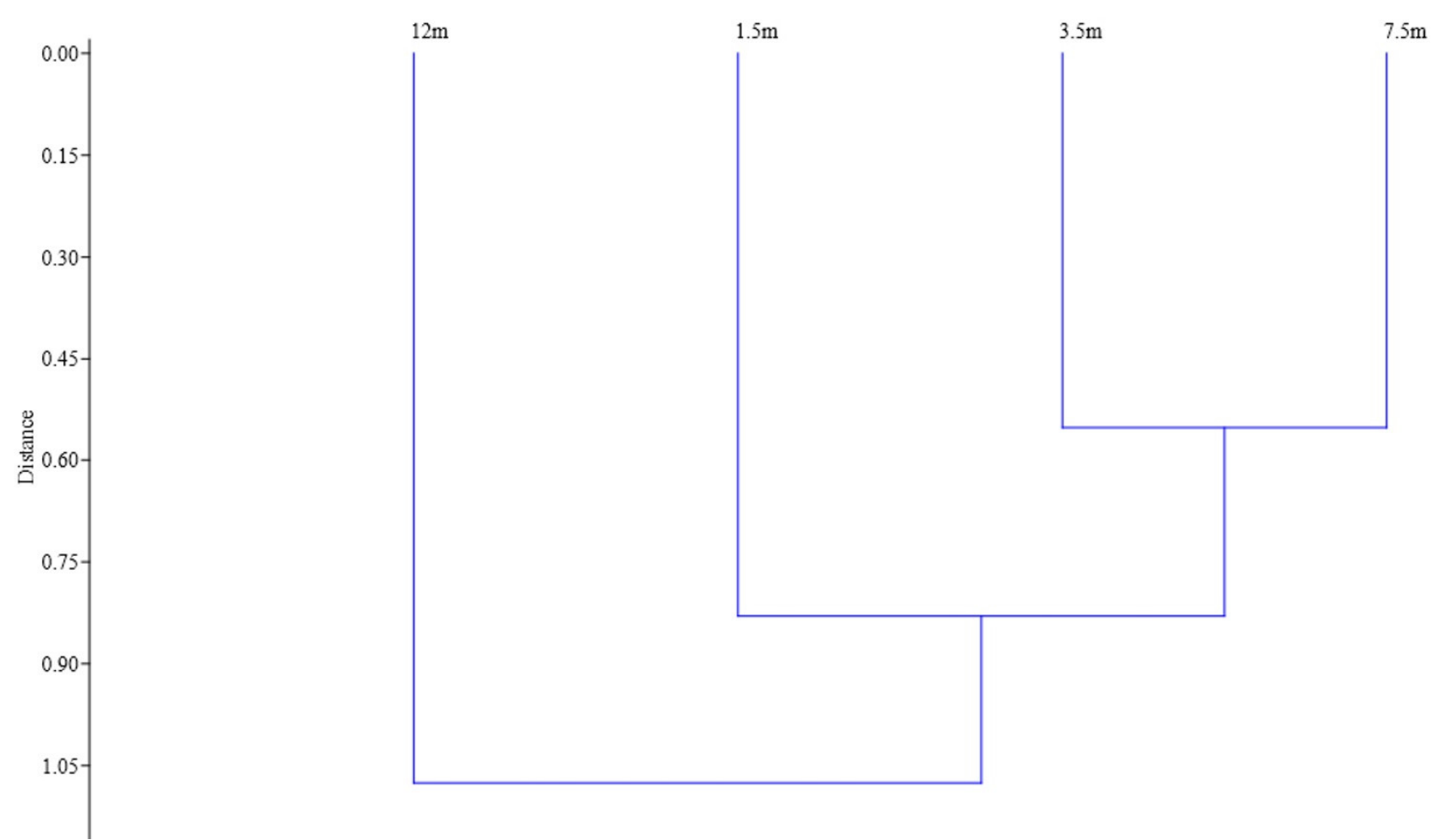

Figure 5. The insect species composition similarity for four studied heights based on Jaccard similarity index, by using Ward's method and Euclidean distances as measurement of Linkage Distance (cophenetic correlation coefficient $=0.670$ ). 
In Figure 6, the spatial arrangement of the selected beetle species demonstrated that the majority of these taxa have no specific preferences to the height in the forest ecosystem. However, five species were exceptions. So, Cryptarcha strigata mostly occurred at heights of $3.5 \mathrm{~m}$ and $7.5 \mathrm{~m}$ with a relatively high abundance. Protaetia marmorata had clear preferences to the highest layer of the forest community $(12 \mathrm{~m})$. Quedius dilatatus also preferred the highest layers of forest crowns, also occurring at an altitude of $7.5 \mathrm{~m}$. In contrary to the previous species, Glischrochilus hortensis and in the lesser degree Cychramus luteus had preferences to inhabit the lowest layers of the forest ecosystem $(1.5 \mathrm{~m})$.

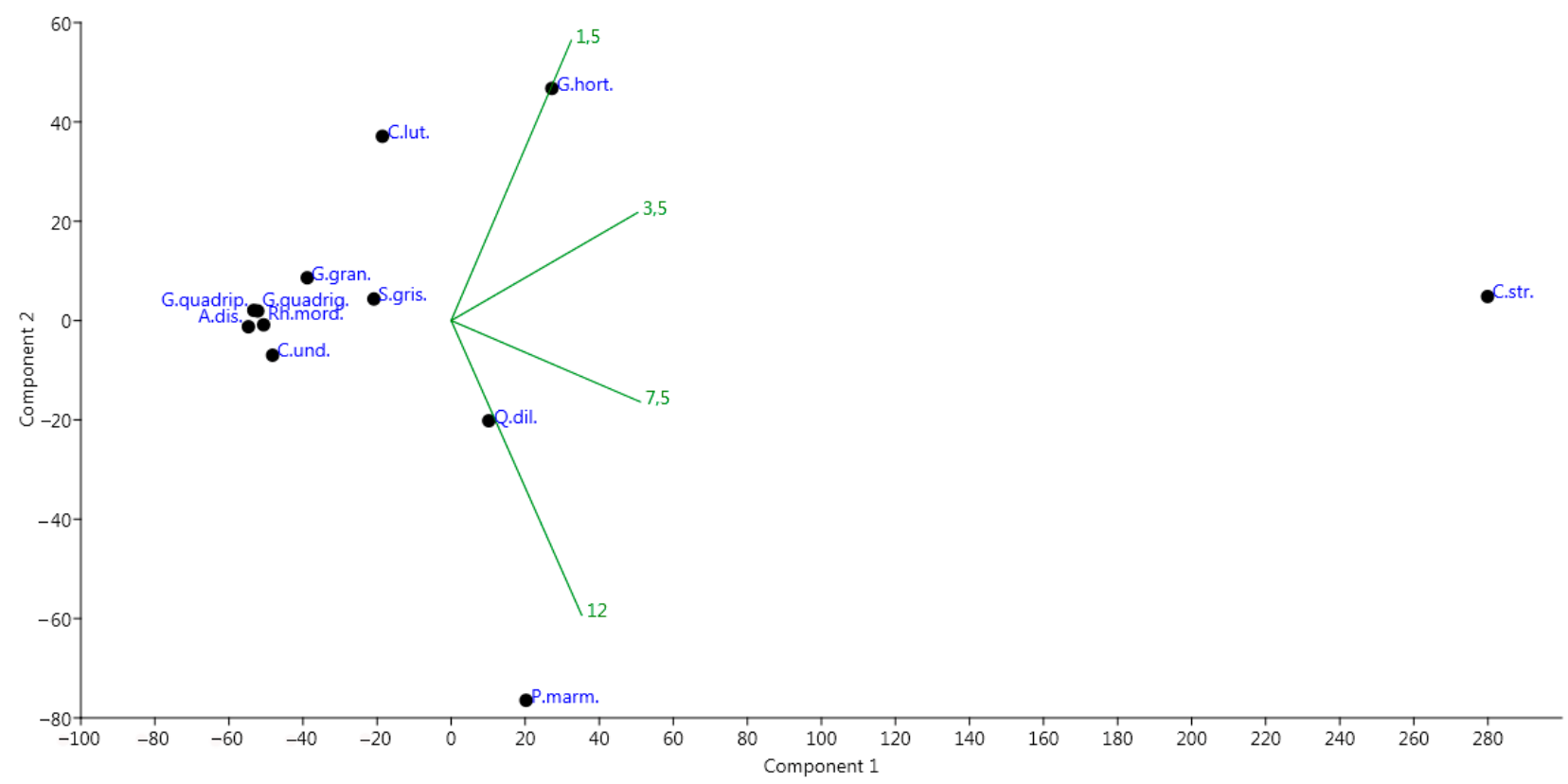

Figure 6. Principal component analysis (PCA) ordination diagram of the abundance species in the Republic of Mordovia (European Russia) based on the number of the collected species exemplars at various height of bait trap positions $(1.5 \mathrm{~m}, 3.5 \mathrm{~m}, 7.5 \mathrm{~m}, 12.0 \mathrm{~m})$. Designations: Q.dil.-Quedius dilatatus; P.marm.-Protaetia marmorata; C.str.-Cryptarcha strigata; C.und.—Cryptarcha undata; C.lut.—Cychramus luteus; G.gran.-Glischrochilus grandis; G.hort.—Glischrochilus hortensis; G.quadrig.-Glischrochilus quadriguttatus; G.quadrip.—Glischrochilus quadripunctatus; S.gris.—Soronia grisea; Rh.mord.Rhagium mordax; A.dis.-Anisandrus dispar. Groups of the height of beer trap positions were plotted onto PCA-ordination diagram as supplementary environmental variables.

The total occurrence of Coleoptera was higher at a height of $1.5 \mathrm{~m}$ and gradually decreased as the height increased, i.e., the higher the traps were located, the lower the occurrence of beetles. Cryptarcha strigata, Protaetia marmorata, Glischrochilus hortensis and Soronia grisea had the highest occurrence rates. Thus, those species whose abundance in traps was high had the highest occurrence rates. Figure 7 shows the analysis of the main components based on the occurrence of the species selected for analysis. Cryptarcha strigata occupies a separate position on the chart due to the highest occurrence value with slightly higher numbers at an altitude of $3.5 \mathrm{~m}$. Soronia grisea was more often found at an altitude of $3.5 \mathrm{~m}$. The occurrence of Protaetia marmorata, Quedius dilatatus and Cryptarcha undata was higher at altitudes of $7.5 \mathrm{~m}$ and $12.0 \mathrm{~m}$, whereas Glischrochilus hortensis, on the contrary, was more common at low altitudes- 1.5 and $3.5 \mathrm{~m}$. Differences are insignificant in the occurrence of other beetle species among heights. 


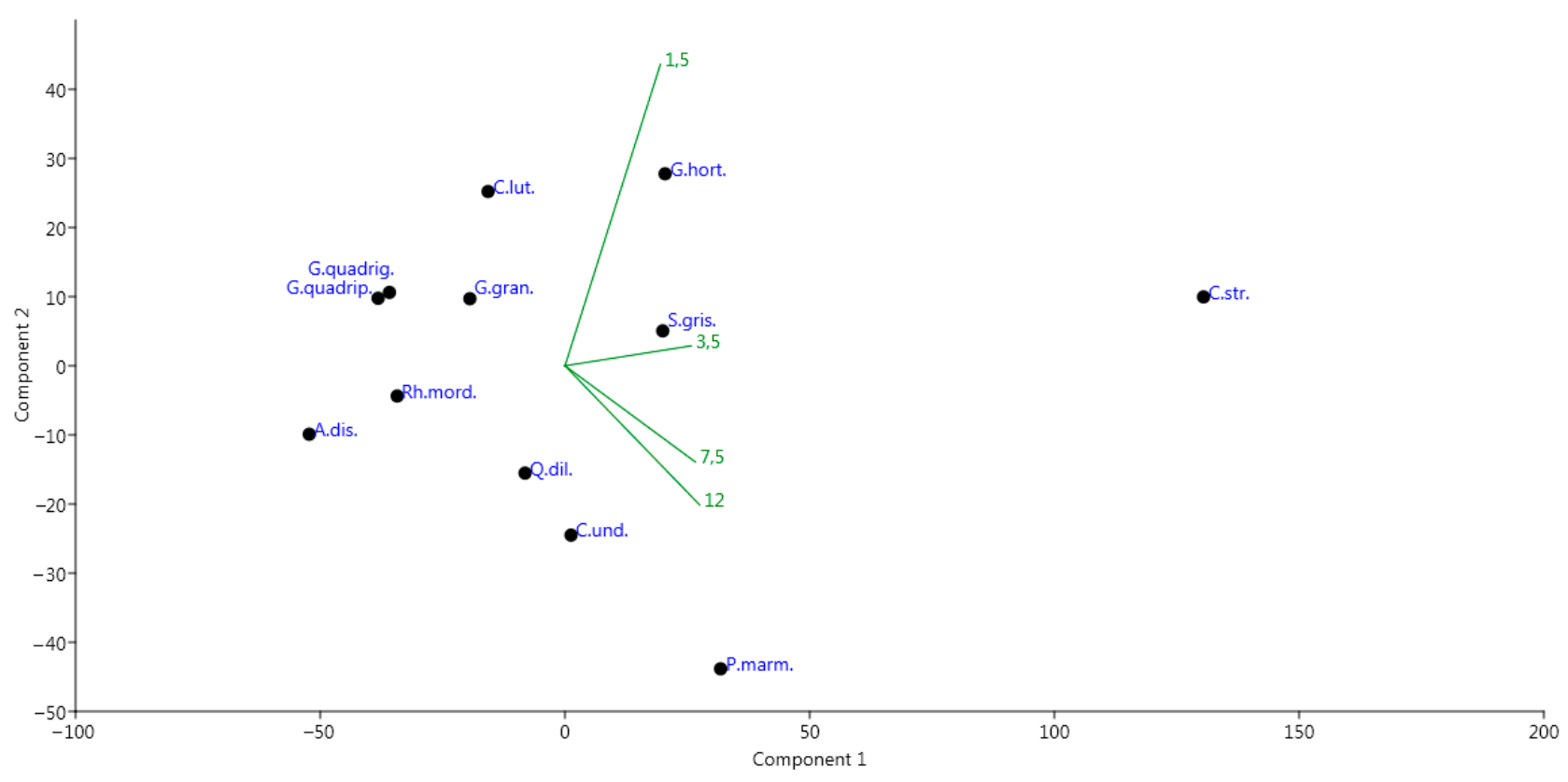

Figure 7. Principal component analysis (PCA) ordination diagram of the species occurrence species in the Republic of Mordovia (European Russia) based on species occurrence of frequency at various height of bait trap positions $(1.5 \mathrm{~m}, 3.5 \mathrm{~m}$, $7.5 \mathrm{~m}, 12.0 \mathrm{~m})$. Designation of species follows one in Figure 5.

\section{Discussion}

This study shows the location of Coleoptera clusters selected using beer traps installed at different heights in temperate forests of European Russia. Different species of Coleoptera fall into such traps, but most of them are species that fly to the fermenting bait. Previously, it was determined that such traps attract a small number of species compared to the total species diversity that falls into these traps. However, the number of specimens actively flying to bait is extremely high and usually amounts to more than $90 \%$ of the total number of specimens [62]. In these studies, we have obtained similar results.

Our results show that the abundance and species diversity of Coleoptera is higher when the trap is set at a height of $1.5 \mathrm{~m}$. The Shannon's diversity index was the highest near the ground than in the tree crowns (at heights of 7.5 and $12 \mathrm{~m}$ ), but there were no differences in total abundance or species richness between the two layers. Ulyshen and Hanula [63] obtained similar results. Thus, there is a small species diversity and dominance of one or more species in the crowns of the tree.

There are some species and families that constantly fall into beer traps. Seven species (Cryptarcha strigata, Glischrochilus hortensis, Protaetia marmorata, Quedius dilatatus, Cychramus luteus, Soronia grisea, Glischrochilus grandis) were the most widespread beetles found in this study. Their total number at all heights exceeded 100 specimens, with an average occurrence ranging from $23 \%$ to $98 \%$. These are species with a wide range and they occur in a wide variety of forest ecosystems, mainly in deciduous and mixed forests [64-71].

According to our research, despite the fact that most beetle species are distributed more or less evenly within the vertical section of the forest, we still identified species that reliably preferred a certain height. For example, Glischrochilus hortensis and to a lesser extent Cychramus luteus preferred to live in the lowest layers of the forest ecosystem $(1.5 \mathrm{~m})$. Glischrochilus hortensis adults are found on the fermenting sap of Quercus robur and under the bark of fallen and dying trees Betula pendula, Populus tremula. Larvae develop under the bark of dying and damaged B. pendula, P. tremula, Q. robur leaves and in their fermented juice. They can also occur on fermented berries, mushrooms and vegetables [72-74]. Cychramus luteus imago are anthophiles and are found on flowers in summer. Later they switch to feeding on Armillaria mellea mushrooms, where their larvae 
develop [75]. Therefore, we assume that both species prefer the lower ground level of the forest. Cryptarcha strigata was mainly found at medium altitudes (undergrowth) with relatively high numbers. Usually imago of this species live near the leaking fermenting juice of $Q$. robur, where preimaginal phases develop. They occasionally fall on the leaking juice of $P$. tremula [73]. The greatest numbers are obtained in biotopes with the predominance of these species [71].

Protaetia marmorata had a clear preference for the highest layer of the forest. Larvae of this species develop in the hollow of dead deciduous trees for 3 years, most often in oaks $[68,71,76]$. Quedius dilatatus also preferred the highest layers of forest layers, occurring as well at an altitude of $7.5 \mathrm{~m}$. It shows a connection with Vespa crabro nests, where its larvae feed on Diptera larvae in the nest debris [77]. It also occurred in wasp nests living in natural conditions. Such nests are located on old oak trees, apple trees, and other deciduous trees. The species was also found on fermenting sap on an oak trunk [78]. Both species of bark beetles Anisandrus dispar and Xyleborinus saxesenii (Ratzeburg, 1837) were caught in the largest number at an height of $1.5 \mathrm{~m}$. The ambrosia beetles Scolytinae (Curculionidae) usually prefer to inhabit the lower parts of the tree crowns, so most of them are trapped at a height of up to $2 \mathrm{~m}$ [79-82].

There is an interesting finding in our study. We have registered a relatively small species diversity of saproxyl beetles at a height of $1.5 \mathrm{~m}$. Saproxylic beetles usually account for $30 \%$ of all Coleoptera species in forest ecosystems [83,84]. Their species diversity is usually higher in warmer forest areas with an abundance of dead wood, dead trees, stumps, coarse wood debris [85-90]. Some authors also associate a significant increase in the species diversity of saproxylic beetles with an increase in temperature in forest areas with dead wood, on illuminated edges [87,91,92]. Schroeder et al. [93] found differences in the composition of Coleoptera living in wood between the understory and canopy of deciduous forests in Canada. Bouget et al. [27] recorded an increase in abundance and species richness of the proximal species in the undergrowth of beech-fir and oak forests. In temperate forests, the proportion of saprophages is higher in the lower tiers of the forest, but in tropical forests, it increased with an increase in the height of traps. This is due to greater competition among individual groups of insects in the lower tiers of tropical forests [4]. However, Vodka and Cizek [24] noticed that the diversity of saproxylic species was higher in the undergrowth than in the canopy at the edge of the forest, while the opposite situation was observed in the depths of the forest. Preisser et al. [94] noticed that 86 out of 101 collected insect families were more numerous in traps at ground level than in traps under the canopy (the authors used two types of traps). Gossner et al. [95] noted an increase in species richness also at the lower levels of the forest. These differences can be caused by reactions at the level of species and families, which are caused by differences in behavior, ability to settle, ecological interactions, microclimate or spatial heterogeneity of the quality and quantity of food [96-99].

It is possible that a bait with a mixture of fermenting beer and sugar has a certain effect on the process. Some authors [100-102] point out that for traps like ours, alcoholic fermentation is a key process for attracting beetles, since in the wild fermented tree sap attracts them. It is possible that at high altitudes there are more such saproxylic beetle species that are attracted to our baits than in the near-surface layer of the forest.

There is no well-developed herbaceous cover in the studied forest, what can cause the decrease in the number of anthophilic beetle species at a height of $1.5 \mathrm{~m}$. A closed grove of trees and a good undergrowth do not allow sunlight to reach the surface of the earth. That is why herbaceous plants do not develop well. On the other hand, many flowering shrubs grow in the undergrowth, where anthophiles find their food. It is also possible that anthophilic species are lured into traps at adjacent heights $(3.5$ and $7.5 \mathrm{~m})$. The significant similarity of species diversity at these heights, calculated by the Jaccard similarity index, can also prove it.

The vertical profile of the air temperature in the forest canopy depends on the time of day, season, crown shape and species of the main tree species $[103,104]$. For example, 
the increased openness of the canopy noticeably changes the undergrowth and grassy layers. This gradient contributes to the vertical distribution of arthropod species in the forest canopy. Consequently, the availability of resources, the richness of microhabitat and abiotic conditions can be considered as critical factors affecting the number of arboreal arthropods. Thus, the insect species composition of the upper parts of the crowns should differ from the lower layers of the forest [4,11,105-107]. In our study, it turned out that the main differences in biodiversity were obtained between heights of 1.5 and $12 \mathrm{~m}$. At the same time, the differences between the heights of 3.5 and $7.5 \mathrm{~m}$ were minimal.

The microclimate of the upper tiers of the forest differs to a certain extent from the microclimate of the undergrowth. In temperate forests, it has special parameters of temperature, humidity, light, and interspecific interactions [108-110]. For example, the surface of the leaves of trees can be much warmer than the air temperature in the upper part of the crown, because they intercept a large amount of incoming radiation [111-113]. Among other things, the complex three-dimensional structure of tree crowns provides an ecological space for reducing insect predation [114-116].

On the other hand, the microclimate in the undergrowth is also different from the crown. For example, the temperature and humidity changes are not so significant. This buffer effect is present in all forests at different latitudes and is relatively independent of tree species [117-119]. The contribution of the understory to the functioning of temperate forests is significant but varies depending on the ecosystem function and ecological context, and, more importantly, the characteristics of the understory [120].

In the surface layer of temperate forests, the average values of temperature and humidity depend on the elements of the structure of the stand. The diameter of the tree, the base area and the variety of sizes affect the amount of scattered light [121]. The shrub layer, the species composition of tree species, dead wood, fallen trees, the remains of stumps are especially important. They can lead to an increase in the species diversity of insects of this tier under certain conditions, such as an increase in the temperature of the nearsurface layer [87,122-126]. In addition, there are species that use microhabitats under the canopy to find partners or prey. Therefore, vertical migrations of individual species occur permanently or temporarily from one tier of the forest to another, depending on the season, the stage of the life cycle and even the time of day $[114,127,128]$. This means that we still have little information about the functioning of arthropod communities living in various tiers of deciduous forests of the temperate zone. To improve the understanding of such interactions, it is necessary to use different methods of data collection, increase the number of research areas, and expand the taxonomic composition of the studied communities.

\section{Conclusions}

Ninety-two species were identified as a result of studies at different heights of deciduous forests in the temperate zone of the European part of Russia. The families Nitidulidae (15 species), Cerambycidae (14 species), Elateridae (seven species), Curculionidae (seven species) and Scarabaeidae (seven species) had the greatest species diversity. Seven species had the maximum number in the traps, and 15 Coleoptera species were common to all the studied heights. The greatest species diversity was obtained at an altitude of $1.5 \mathrm{~m}$, the smallest—at an altitude of $7.5 \mathrm{~m}$. The highest abundance values were obtained at altitudes of 1.5 and $3.5 \mathrm{~m}$. The minimum number of specimens was caught at a height of $12 \mathrm{~m}$. The largest differences in the Jaccard similarity index were obtained between samples from a height of 1.5 and $12 \mathrm{~m}$. The Shannon's diversity index was higher near the ground than in the tree crowns (at heights of 7.5 and $12 \mathrm{~m}$ ), and the Simpson's Diversity index had the opposite trend. Glischrochilus hortensis and to a lesser extent Cychramus luteus preferred to live in the lowest layers of deciduous forest $(1.5 \mathrm{~m})$. Cryptarcha strigata was mainly found at altitudes of $3.5 \mathrm{~m}$ and $7.5 \mathrm{~m}$ with relatively high numbers. The abundance and occurrence of Protaetia marmorata were higher in the uppermost layers of the crowns. Quedius dilatatus also preferred the highest parts of the crown, also occurring at an altitude of $7.5 \mathrm{~m}$. The number of saproxylic beetle species was practically the same at altitudes of 3.5-12 m, while 
their relative number decreased in the surface layer. The relative number of anthophilic beetle species was also lower at low height. We think that in order to manage forests to increase species diversity, it is necessary to try not only to increase the amount of dead wood for saproxyl species. Of great importance is the improvement of the herbaceous cover for anthophilic insects.

Author Contributions: Conceptualization, A.B.R.; methodology, A.B.R.; validation, L.V.E. and A.B.R.; formal analysis, L.V.E. and A.B.R.; investigation, A.B.R.; data curation, A.B.R.; writing—original draft preparation, A.B.R.; writing - review and editing, L.V.E. and A.B.R. All authors have read and agreed to the published version of the manuscript.

Funding: The research for this paper had no direct external funding to the authors.

Institutional Review Board Statement: Not applicable.

Informed Consent Statement: Not applicable.

Data Availability Statement: The data presented in this study are available in Table A1.

Acknowledgments: The authors are grateful to A.A. Khapugin (Saransk, Tyumen) for his help in conducting a statistical analysis of the obtained results.

Conflicts of Interest: The authors declare no conflict of interest.

\section{Appendix A}

Table A1. Species diversity, total $(\mathrm{T})$, mean number $(\mathrm{M}, \%)$, and occurrence $(\mathrm{O}, \%)$ of coleoptera individuals collected using beer traps at different heights.

\begin{tabular}{|c|c|c|c|c|c|c|c|c|c|c|c|c|}
\hline \multirow{2}{*}{ Species } & \multicolumn{3}{|c|}{$1.5 \mathrm{~m}$} & \multicolumn{3}{|c|}{$3.5 \mathrm{~m}$} & \multicolumn{3}{|c|}{$7.5 \mathrm{~m}$} & \multicolumn{3}{|c|}{$12 \mathrm{~m}$} \\
\hline & $\mathbf{T}$ & $\mathbf{M}$ & $\mathbf{O}$ & $\mathbf{T}$ & $\mathbf{M}$ & $\mathbf{O}$ & $\mathbf{T}$ & $\mathbf{M}$ & $\mathbf{O}$ & $\mathbf{T}$ & $\mathbf{M}$ & $\mathbf{O}$ \\
\hline Carabidae & & & & & & & & & & & & \\
\hline Calosoma inquisitor (Linnaeus, 1758) & 9 & 0.26 & 4.65 & & & & & & & & & \\
\hline Limodromus assimilis (Paykull, 1790) & 5 & 0.14 & 2.33 & 3 & 0.09 & 2.33 & & & & & & \\
\hline Histeridae & & & & & & & & & & & & \\
\hline Hister unicolor Linnaeus, 1758 & 1 & 0.03 & 2.33 & & & & & & & & & \\
\hline Gnathoncus buyssoni Auzat, 1917 & & & & & & & 1 & 0.02 & 2.33 & 1 & 0.02 & 2.33 \\
\hline $\begin{array}{c}\text { Margarinotus striola (C.R. Sahlberg, } \\
\text { 1819) }\end{array}$ & 12 & 0.27 & 11.63 & & & & & & & & & \\
\hline $\begin{array}{l}\text { Platysoma lineare Erichson, } 1834 \\
\text { Silphidae }\end{array}$ & 2 & 0.04 & 4.65 & & & & & & & & & \\
\hline $\begin{array}{c}\text { Dendroxena quadrimaculata } \\
\text { (Scopoli, 1771) }\end{array}$ & 1 & 0.02 & 2.33 & 3 & 0.07 & 4.65 & 3 & 0.07 & 4.65 & 8 & 0.19 & 11.63 \\
\hline Necrodes littoralis (Linnaeus, 1758) & 4 & 0.09 & 9.3 & & & & 1 & 0.02 & 2.33 & & & \\
\hline Nicrophorus vespilloides Herbst, 1783 & & & & & & & & & & 2 & 0.04 & 2.33 \\
\hline $\begin{array}{c}\text { Oiceoptoma thoracicum (Linnaeus, 1758) } \\
\text { Staphylinidae }\end{array}$ & 28 & 0.73 & 18.6 & 4 & 0.1 & 9.3 & 1 & 0.02 & 2.33 & & & \\
\hline Staphylinidae sp. & 180 & 4.2 & 76.74 & 86 & 1.98 & 65.12 & 52 & 1.28 & 51.16 & 16 & 0.38 & 27.9 \\
\hline $\begin{array}{c}\text { Quedius dilatatus (Fabricius, 1787) } \\
\text { Scarabaeidae }\end{array}$ & 39 & 0.86 & 20.93 & 196 & 4.36 & 27.91 & 243 & 5.72 & 34.88 & 165 & 3.83 & 27.91 \\
\hline Cetonia aurata (Linnaeus, 1758) & 1 & 0.02 & 2.33 & & & & 1 & 0.02 & 2.33 & 3 & 0.07 & 2.33 \\
\hline Gnorimus variabilis (Linnaeus, 1758) & & & & & & & & & & 1 & 0.03 & 2.33 \\
\hline Protaetia fieberi (Kraatz, 1880) & 3 & 0.09 & 2.33 & & & & 3 & 0.08 & 4.65 & 18 & 0.49 & 13.95 \\
\hline Protaetia marmorata (Fabricus, 1792) & 7 & 0.16 & 11.63 & 83 & 1.99 & 48.84 & 223 & 5.54 & 58.14 & 508 & 12.5 & 65.12 \\
\hline Protaetia speciosissima (Scopoli, 1786) & & & & & & & & & & 1 & 0.03 & 2.33 \\
\hline Protaetia metallica (Herbst, 1782) & & & & & & & & & & 1 & 0.03 & 2.33 \\
\hline Serica brunnea (Linnaeus, 1758) & 2 & 0.04 & 4.65 & & & & & & & & & \\
\hline Scirtidae & & & & & & & & & & & & \\
\hline Contacyphon sp. & 1 & 0.02 & 2.33 & & & & 1 & 0.03 & 2.33 & 1 & 0.02 & 2.33 \\
\hline Microcara testacea (Linnaeus,1767) & & & & & & & & & & 1 & 0.03 & 2.33 \\
\hline
\end{tabular}


Table A1. Cont.

\begin{tabular}{|c|c|c|c|c|c|c|c|c|c|c|c|c|}
\hline \multirow{2}{*}{ Species } & \multicolumn{3}{|c|}{$1.5 \mathrm{~m}$} & \multicolumn{3}{|c|}{$3.5 \mathrm{~m}$} & \multicolumn{3}{|c|}{$7.5 \mathrm{~m}$} & \multicolumn{3}{|c|}{$12 \mathrm{~m}$} \\
\hline & $\mathbf{T}$ & $\mathbf{M}$ & $\mathbf{O}$ & $\mathbf{T}$ & $\mathbf{M}$ & $\mathbf{O}$ & $\mathbf{T}$ & $\mathbf{M}$ & $\mathbf{O}$ & $\mathbf{T}$ & $\mathbf{M}$ & $\mathbf{O}$ \\
\hline Elateridae & & & & & & & & & & & & \\
\hline Ampedus pomorum (Herbst, 1784) & & & & & & & 1 & 0.02 & 2.33 & & & \\
\hline Athous haemorrhoidalis (Fabricius, 1801) & 2 & 0.06 & 2.33 & 1 & 0.03 & 2.33 & 1 & 0.03 & 2.33 & & & \\
\hline Athous subfuscus (O.F. Müller, 1764) & 1 & 0.02 & 2.33 & & & & & & & & & \\
\hline Dalopius marginatus (Linnaeus, 1758) & & & & & & & 1 & 0.02 & 2.33 & & & \\
\hline Denticollis linearis (Linnaeus, 1758) & 1 & 0.02 & 2.33 & & & & & & & 1 & 0.02 & 2.33 \\
\hline Elater ferrugineus Linnaeus, 1758 & & & & & & & & & & 1 & 0.03 & 2.33 \\
\hline Melanotus castanipes (Paykull, 1800) & & & & & & & & & & 1 & 0.02 & 2.33 \\
\hline \multicolumn{13}{|l|}{ Buprestidae } \\
\hline $\begin{array}{l}\text { Agrilus sp. } \\
\text { Lampyridae }\end{array}$ & & & & & & & 1 & 0.02 & 2.33 & & & \\
\hline $\begin{array}{c}\text { Lampyris noctiluca (Linnaeus, 1758) } \\
\text { Cantharidae }\end{array}$ & 4 & 0.09 & 4.65 & & & & & & & & & \\
\hline Cantharis nigricans O.F. Müller, 1776 & 3 & 0.07 & 6.98 & 2 & 0.04 & 2.33 & 1 & 0.03 & 2.33 & 3 & 0.07 & 6.98 \\
\hline \multicolumn{13}{|l|}{ Dermestidae } \\
\hline & \multicolumn{11}{|c|}{ Ptinidae } & 6.98 \\
\hline Dorcatoma robusta A. Strand, 1938 & 1 & 0.02 & 2.33 & & & & & & & & & \\
\hline \multicolumn{12}{|l|}{ Melyridae } & 2.33 \\
\hline Dasytes fusculus (Illiger, 1801) & & & & & & & 1 & 0.02 & 2.33 & & & \\
\hline Dasytes niger (Linnaeus, 1760) & 8 & 0.02 & 2.33 & 1 & 0.02 & 2.33 & & & & & & \\
\hline \multicolumn{13}{|l|}{ Monotomidae } \\
\hline Rhizophagus fenestralis (Linnaeus, 1758) & 3 & 0.07 & 6.98 & 1 & 0.02 & 2.33 & & & & & & \\
\hline $\begin{array}{l}\text { Rhizophagus picipes } \\
\text { (G.-A. Olivier, 1790) }\end{array}$ & 1 & 0.03 & 2.33 & & & & & & & & & \\
\hline \multicolumn{13}{|l|}{ Nitidulidae } \\
\hline Cryptarcha strigata (Fabricius, 1787) & 665 & 14.9 & 97.67 & 993 & 22.7 & 100 & 993 & 23.15 & 97.67 & 664 & 15.6 & 97.67 \\
\hline Cryptarcha undata (G.-A.Olivier, 1790) & 9 & 0.21 & 16.28 & 24 & 0.58 & 34.88 & 27 & 0.65 & 37.21 & 37 & 0.94 & 39.53 \\
\hline Cychramus luteus (Fabricius, 1787) & 307 & 6.82 & 55.81 & 88 & 1.96 & 20.93 & 36 & 0.84 & 16.28 & 21 & 0.48 & 13.95 \\
\hline Cychramus variegatus (Herbst, 1792) & 5 & 0.11 & 9.3 & 5 & 0.11 & 9.3 & & & & & & \\
\hline Cyllodes ater (Herbst, 1792) & 1 & 0.02 & 2.33 & 2 & 0.04 & 4.65 & & & & & & \\
\hline Epuraea guttata (G.-A. Olivier, 1811) & 7 & 0.15 & 13.95 & 5 & 0.12 & 11.63 & 4 & 0.1 & 6.98 & & & \\
\hline Epuraea sp. & 91 & 2.2 & 58.14 & 40 & 0.95 & 41.86 & 21 & 0.51 & 27.91 & 40 & 0.9 & 16.28 \\
\hline Glischrochilus grandis (Tournier, 1872) & 78 & 1.92 & 37.21 & 81 & 1.87 & 27.91 & 24 & 0.58 & 18.6 & 11 & 0.26 & 11.63 \\
\hline Glischrochilus hortensis (Geoffroy, 1785) & 392 & 8.96 & 69.76 & 291 & 6.51 & 46.51 & 127 & 3.06 & 32.56 & 81 & 1.95 & 30.23 \\
\hline $\begin{array}{l}\text { Glischrochilus quadriguttatus } \\
\text { (Fabricius, 1777) }\end{array}$ & 35 & 0.79 & 30.23 & 18 & 0.41 & 23.26 & 8 & 0.2 & 9.3 & & & \\
\hline $\begin{array}{l}\text { Glischrochilus quadripunctatus } \\
\text { (Linnaeus, 1758) }\end{array}$ & 39 & 0.87 & 30.23 & 11 & 0.24 & 18.6 & 2 & 0.04 & 4.65 & 2 & 0.04 & 4.65 \\
\hline Glischrochilus quadrisignatus (Say, 1835) & & & & 1 & 0.02 & 2.33 & 1 & 0.02 & 2.33 & 1 & 0.02 & 2.33 \\
\hline Meligethes sp. & & & & & & & & & & 1 & 0.03 & 2.33 \\
\hline Omosita depressa (Linnaeus, 1758) & 1 & 0.02 & 2.33 & 1 & 0.02 & 2.33 & & & & & & \\
\hline Omosita discoidea (Fabricius, 1775) & & & & & & & 1 & 0.02 & 2.33 & & & \\
\hline Soronia grisea (Linnaeus, 1758) & 82 & 1.99 & 46.51 & 143 & 3.57 & 53.49 & 84 & 2.17 & 39.53 & 52 & 1.29 & 32.56 \\
\hline Soronia punctatissima (Illiger, 1794) & 1 & 0.02 & 2.33 & 1 & 0.02 & 2.33 & 1 & 0.02 & 2.33 & & & \\
\hline \multicolumn{13}{|l|}{ Cucujidae } \\
\hline Cucujus haematodes (Erichson, 1845) & 1 & 0.03 & 2.33 & & & & & & & & & \\
\hline Pediacus depressus (Herbst, 1797) & 4 & 0.09 & 6.98 & & & & & & & 1 & 0.03 & 2.33 \\
\hline \multicolumn{13}{|l|}{ Coccinellidae } \\
\hline Calvia decemguttata (Linnaeus, 1767) & 1 & 0.02 & 2.33 & & & & 1 & 0.02 & 2.33 & 1 & 0.03 & 2.33 \\
\hline $\begin{array}{l}\text { Chilocorus renipustulatus } \\
\text { (L.G. Scriba, 1791) }\end{array}$ & 1 & 0.03 & 2.33 & & & & & & & & & \\
\hline $\begin{array}{l}\text { Psyllobora vigintiduopunctata } \\
\text { (Linnaeus, 1758) }\end{array}$ & 1 & 0.03 & 2.33 & & & & & & & & & \\
\hline
\end{tabular}


Table A1. Cont.

\begin{tabular}{|c|c|c|c|c|c|c|c|c|c|c|c|c|}
\hline \multirow{2}{*}{ Species } & \multicolumn{3}{|c|}{$1.5 \mathrm{~m}$} & \multicolumn{3}{|c|}{$3.5 \mathrm{~m}$} & \multicolumn{3}{|c|}{$7.5 \mathrm{~m}$} & \multicolumn{3}{|c|}{$12 \mathrm{~m}$} \\
\hline & $\mathbf{T}$ & $\mathbf{M}$ & $\mathbf{O}$ & $\mathbf{T}$ & $\mathbf{M}$ & $\mathbf{O}$ & $\mathbf{T}$ & $\mathbf{M}$ & $\mathbf{O}$ & $\mathbf{T}$ & $\mathbf{M}$ & $\mathbf{O}$ \\
\hline Melandryidae & & & & & & & & & & & & \\
\hline Orchesia fasciata (Illiger, 1798) & & & & & & & & & & 1 & 0.02 & 2.33 \\
\hline Orchesia micans (Panzer, 1793) & 1 & 0.02 & 2.33 & & & & & & & & & \\
\hline Phloiotrya subtilis (Reitter, 1897) & & & & 1 & 0.02 & 2.33 & & & & & & \\
\hline Mycetophagidae & & & & & & & & & & & & \\
\hline Litargus connexus (Geoffroy, 1785) & 2 & 0.05 & 4.65 & 2 & 0.04 & 4.65 & & & & & & \\
\hline Mycetophagus ater (Reitter, 1879) & 1 & 0.02 & 2.33 & & & & & & & 1 & 0.02 & 2.33 \\
\hline Mycetophagus piceus (Fabricius, 1777) & & & & 1 & 0.02 & 2.33 & & & & & & \\
\hline $\begin{array}{l}\text { Mycetophagus quadripustulatus } \\
\text { (Linnaeus, 1760) }\end{array}$ & 1 & 0.02 & 2.33 & 1 & 0.02 & 2.33 & & & & & & \\
\hline Mordellidae & & & & & & & & & & & & \\
\hline $\begin{array}{l}\text { Mordellochroa abdominalis } \\
\text { (Fabricius, 1775) }\end{array}$ & 1 & 0.02 & 2.33 & & & & & & & & & \\
\hline Tomoxia bucephala A. Costa, 1854 & & & & & & & & & & 1 & 0.02 & 2.33 \\
\hline Tenebrionidae & & & & & & & & & & & & \\
\hline $\begin{array}{l}\text { Bolitophagus reticulatus } \\
\quad \text { (Linnaeus, 1767) }\end{array}$ & & & & 1 & 0.03 & 2.33 & & & & & & \\
\hline Lagria hirta (Linnaeus, 1758) & 1 & 0.02 & 2.33 & 1 & 0.02 & 2.33 & & & & & & \\
\hline Pyrochroidae & & & & & & & & & & & & \\
\hline Schizotus pectinicornis (Linnaeus, 1758) & & & & & & & & & & 1 & 0.03 & 2.33 \\
\hline Pyrochroa coccinea (Linnaeus, 1760) & & & & & & & & & & 1 & 0.02 & 2.33 \\
\hline Cerambycidae & & & & & & & & & & & & \\
\hline Alosterna ingrica (Baeckmann, 1902) & 1 & 0.02 & 2.33 & 1 & 0.02 & 2.33 & & & & & & \\
\hline Alosterna tabacicolor (De Geer, 1775) & & & & & & & & & & 4 & 0.09 & 2.33 \\
\hline Anoplodera sexguttata (Fabricius, 1775) & & & & 1 & 0.02 & 2.33 & & & & & & \\
\hline Dinoptera collaris (Linnaeus, 1758 ) & 1 & 0.02 & 2.33 & 1 & 0.02 & 2.33 & 1 & 0.02 & 2.33 & 1 & 0.03 & 2.33 \\
\hline Leptura quadrifasciata Linnaeus, 1758 & 9 & 0.2 & 11.63 & 6 & 0.13 & 9.3 & 4 & 0.09 & 6.98 & 4 & 0.09 & 9.3 \\
\hline Leptura thoracica (Creutzer, 1799) & 2 & 0.04 & 2.33 & 7 & 0.16 & 4.65 & 6 & 0.14 & 6.98 & 5 & 0.12 & 9.3 \\
\hline Molorchus minor (Linnaeus, 1758) & & & & & & & 2 & 0.04 & 4.65 & & & \\
\hline Necydalis major Linnaeus, 1758 & & & & 1 & 0.02 & 2.33 & 1 & 0.03 & 2.33 & 1 & 0.03 & 2.33 \\
\hline Nivellia sanguinosa (Gyllenhal, 1827) & & & & 3 & 0.07 & 6.98 & & & & & & \\
\hline Obrium cantharinum (Linnaeus, 1767) & & & & & & & 1 & 0.03 & 2.33 & & & \\
\hline Oplosia cinerea (Mulsant, 1839) & 1 & 0.02 & 2.33 & & & & & & & & & \\
\hline Rhagium mordax (DeGeer, 1775) & 42 & 0.94 & 23.26 & 9 & 0.2 & 9.3 & 10 & 0.22 & 11.63 & 23 & 0.56 & 18.6 \\
\hline Rhagium sycophanta (Schrank, 1781) & 1 & 0.03 & 2.33 & & & & 1 & 0.02 & 2.33 & 2 & 0.06 & 2.33 \\
\hline Stenocorus meridianus (Linnaeus, 1758) & & & & 2 & 0.04 & 4.65 & 1 & 0.03 & 2.33 & & & \\
\hline Orsodacnidae & & & & & & & & & & & & \\
\hline Orsodacne cerasi (Linnaeus, 1758) & & & & & & & & & & 1 & 0.03 & 2.33 \\
\hline Anthribidae & & & & & & & & & & & & \\
\hline Gonotropis dorsalis (Gyllenhal, 1813) & & & & & & & 1 & 0.03 & 2.33 & & & \\
\hline Curculionidae & & & & & & & & & & & & \\
\hline Anisandrus dispar (Fabricius, 1792) & 19 & 0.52 & 9.3 & 6 & 0.16 & 4.65 & 6 & 0.16 & 6.98 & 4 & 0.11 & 4.65 \\
\hline Phyllobius argentatus (Linnaeus, 1758) & 4 & 0.09 & 6.98 & 6 & 0.13 & 9.3 & & & & 1 & 0.02 & 2.33 \\
\hline Phyllobius jacobsoni Smirnov, 1913 & & & & & & & & & & 1 & 0.02 & 2.33 \\
\hline Phyllobius pomaceus Gyllenhal, 1834 & 2 & 0.06 & 2.33 & & & & 1 & 0.03 & 2.33 & & & \\
\hline Platystomos albinus (Linnaeus, 1758) & & & & & & & & & & 1 & 0.02 & 2.33 \\
\hline Strophosoma capitatum (DeGeer, 1775) & 1 & 0.02 & 2.33 & & & & & & & & & \\
\hline Xyleborinus saxesenii (Ratzeburg, 1837) & 3 & 0.09 & 2.33 & & & & & & & & & \\
\hline
\end{tabular}

\section{References}

1. Romano, V.A.; Rosati, L.; Fascetti, S. Trends in population size of Ophrys argolica subsp. biscutella in the Appennino Lucano-Val d'Agri-Lagonegrese National Park (Italy). Nat. Conserv. Res. 2020, 5 (Suppl. S1), 155-164. [CrossRef]

2. Sergeev, M.E. Species composition and biotopic distribution of leaf beetles (Coleoptera: Megalopodidae, Chrysomelidae) in the Sikhote-Alin State Nature Reserve (Russia). Nat. Conserv. Res. 2020, 5, 80-88. [CrossRef]

3. Popkova, T.V.; Zryanin, V.A.; Ruchin, A.B. The ant fauna (Hymenoptera: Formicidae) of the Mordovia State Nature Reserve, Russia. Nat. Conserv. Res. 2021, 6, 45-57. [CrossRef] 
4. Weiss, M.; Didham, R.K.; Procházka, J.; Schlaghamerský, J.; Basset, Y.; Odegaard, F.; Tichechkin, A.; Schmidl, J.; Floren, A.; Curletti, G.; et al. Saproxylic beetles in tropical and temperate forests-A standardized comparison of vertical stratification patterns. For. Ecol. Manag. 2019, 444, 50-58. [CrossRef]

5. DeVries, P.J. Stratification of fruit-feeding nymphalid butterflies in a Costa Rican rainforest. J. Res. Lepid. 1988, 26, 98-108.

6. Santos, J.; Iserhard, C.; Carreira, J.; Freitas, A. Monitoring fruit-feeding butterfly assemblages in two vertical strata in seasonal Atlantic forest: Temporal species turnover is lower in the canopy. J. Trop. Ecol. 2017, 33, 345-355. [CrossRef]

7. Ruchin, A.B. Seasonal dynamics and spatial distribution of lepidopterans in selected locations in Mordovia, Russia. Biodiversitas 2021, 22, 2569-2575. [CrossRef]

8. Rubik, D.W. Tropical pollinators in the canopy and understory: Field data and theory for stratum preferences. J. Insect Behav. 1993, 6, 659-673. [CrossRef]

9. Ulyshen, M.D.; Soon, V.; Hanula, J.L. Vertical distribution and seasonality of predatory wasps (Hymenoptera: Vespidae) in a temperate deciduous forest. Fla. Entomol. 2011, 94, 1068-1070. [CrossRef]

10. Giovanni, F.; Mei, M.; Cerretti, P. Vertical stratification of selected Hymenoptera in a remnant forest of the Po Plain (Italy, Lombardy) (Hymenoptera: Ampulicidae, Crabronidae, Sphecidae). Fragm. Entomol. 2017, 49, 71-77. [CrossRef]

11. Urban-Mead, K.R.; Muñiz, P.; Gillung, J.; Espinoza, A.; Fordyce, R.; van Dyke, M.; McArt, S.H.; Danforth, B.N. Bees in the trees: Diverse spring fauna in temperate forest edge canopies. For. Ecol. Manag. 2021, 482, 118903. [CrossRef]

12. Gruppe, A.; Schubert, H. The spatial distribution and plant specificity of Neuropterida in different forest sites in Southern Germany (Raphidioptera and Neuroptera). Beitr. Zur Entomol. 2001, 51, 517-527. [CrossRef]

13. Makarkin, V.N.; Ruchin, A.B. Materials on the Neuroptera and Raphidioptera fauna in Mordovia and adjacent regions of European Russia. Proc. Mordovia State Nat. Reserve 2020, 24, 161-181.

14. Kato, M.; Inque, T.; Hamid, A.A.; Nagamitsu, T.; Merdek, M.B.; Nona, A.R.; Itino, T.; Yamane, S.; Yumoto, T. Seasonality and vertical structure of light-attracted insect communities in a dipterocarp forest in Sarawak. Res. Popul. Ecol. 1995, 37, 59-79. [CrossRef]

15. Birtele, D.; Hardersen, S. Analysis of vertical stratification of Syrphidae (Diptera) in an oak-hornbeam forest in northern Italy. Ecol. Res. 2012, 27, 755-763. [CrossRef]

16. Dvořák, L.; Dvořáková, K.; Oboňa, J.; Ruchin, A.B. Selected Diptera families caught with beer traps in the Republic of Mordovia (Russia). Nat. Conserv. Res. 2020, 5, 65-77. [CrossRef]

17. Sutton, S.L.; Hudson, P.J. The vertical distribution of small flying insects in the lowland rain forest of Zaire. Zool. J. Linn. Soc. 1980, 68, 111-124. [CrossRef]

18. Kirstová, M.; Pyszko, P.; Šipoš, J.; Drozd, P.; Kočárek, P. Vertical distribution of earwigs (Dermaptera: Forficulidae) in a temperate lowland forest, based on sampling with a mobile aerial lift platform. Entomol. Sci. 2017, 20, 57-64. [CrossRef]

19. Procházka, J.; Cizek, L.; Schlaghamerský, J. Vertical stratification of scolytine beetles in temperate forests. Insect Conserv. Divers. 2018, 11, 534-544. [CrossRef]

20. Charles, E.; Basset, Y. Vertical stratification of leaf-beetle assemblages (Coleoptera: Chrysomelidae) in two forest types in Panama. J. Trop. Ecol. 2005, 21, 329-336. [CrossRef]

21. Graham, E.E.; Poland, T.M.; McCullough, D.G.; Millar, J.G. A comparison of trap type and height for capturing cerambycid beetles (Coleoptera). J. Econ. Entomol. 2012, 105, 837-846. [CrossRef]

22. Vance, C.C.; Kirby, K.R.; Malcolm, J.R.; Smith, S.M. Community composition of longhorned beetles (Coleoptera: Cerambycidae) in the canopy and understorey of sugar maple and white pine stands in south-central Ontario. Environ. Entomol. 2003, 32, 1066-1074. [CrossRef]

23. Puker, A.; Correa, C.M.A.; Silva, A.S.; Silva, J.V.O.; Korasaki, V.; Grossi, P.C. Effects of fruit-baited trap height on flower and leaf chafer scarab beetles sampling in Amazon rainforest. Entom. Sci. 2020, 23, 245-255. [CrossRef]

24. Vodka, Š.; Cizek, L. The effects of edge-interior and understorey-canopy gradients on the distribution of saproxylic beetles in a temperate lowland forest. For. Ecol. Manag. 2013, 304, 33-41. [CrossRef]

25. Stork, N.E.; Grimbacher, P.S. Beetle assemblages from an Australian tropical rainforest show that the canopy and the ground strata contribute equally to biodiversity. Proc. R. Soc. B Biol. Sci. 2006, 273, 1969-1975. [CrossRef]

26. Hirao, T.; Murakami, M.; Kashizaki, A. Importance of the understory stratum to entomofaunal diversity in a temperate deciduous forest. Ecol. Res. 2009, 24, 263-272. [CrossRef]

27. Bouget, C.; Brin, A.; Brustel, H. Exploring the "last biotic frontier": Are temperate forest canopies special for saproxylic beetles? For. Ecol. Manag. 2011, 261, 211-220. [CrossRef]

28. Butler, L.; Kondo, V.; Barrows, E.M.; Townsend, E.C. Effects of Weather Conditions and Trap Types on Sampling for Richness and Abundance of Forest Macrolepidoptera. Environ. Entomol. 1999, 28, 795-811. [CrossRef]

29. Matos-Maraví, P.; Ritter, C.D.; Barnes, C.J.; Nielsen, M.; Olsson, U.; Wahlberg, N.; Marquina, D.; Sääksjärvi, I.; Antonelli, A. Biodiversity seen through the perspective of insects: 10 simple rules on methodological choices and experimental design for genomic studies. PeerJ 2019, 7, e6727. [CrossRef] [PubMed]

30. Diabaté, D.; Tano, Y. Efficiencies of three insect collection methods in Lamto, Côte d'Ivoire. Int. J. Biodivers. Conserv. 2020, 12, 153-158. [CrossRef]

31. Schieffer, T.L.; Bright, D.E. Xylosandrus mutilatus (Blandford), an exotic ambrosia beetle (Coleoptera: Curculionidae: Scolytinae: Xyleborini) new to North America. Coleop. Bull. 2004, 58, 431-438. [CrossRef] 
32. Dodds, K. Effects of trap height on captures of arboreal insects in pine stands of northeastern United States of America. Can. Entomol. 2014, 146, 80-89. [CrossRef]

33. Sweeney, J.; Hughes, C.; Webster, V.; Kostanowicz, C.; Webster, R.; Mayo, P.; Allison, J.D. Impact of horizontal edge-interior and vertical canopy-understory gradients on the abundance and diversity of bark and woodboring beetles in survey traps. Insects 2020, 11, 573. [CrossRef] [PubMed]

34. Foit, J.; Čermák, V.; Gaar, V.; Hradil, K.; Nový, V.; Rolincová, P. New insights into the life history of Monochamus galloprovincialis can enhance surveillance strategies for the pinewood nematode. J. Pest Sci. 2019, 92, 1203-1215. [CrossRef]

35. Touroult, J.; Dalens, P.H. Beetles vertical stratification in French Guiana'forests: Study using aerial fruit traps. ACOREP-France Coléoptères de Guyane 2012, 6, 16-24.

36. Rassati, D.; Marini, L.; Marchioro, M.; Rapuzzi, P.; Magnani, G.; Poloni, R.; Di Giovanni, F.; Mayo, P.; Sweeney, J. Developing trapping protocols for wood-boring beetles associated with broadleaf trees. J. Pest Sci. 2019, 92, 267-279. [CrossRef]

37. Miller, D.R.; Crowe, C.M.; Sweeney, J.D. Trap height affects catches of bark and woodboring beetles (Coleoptera: Curculionidae, Cerambycidae) in baited multiple-funnel traps in Southeastern United States. J. Econ. Entomol. 2020, 113, 273-280. [CrossRef]

38. Ruchin, A.B.; Makarkin, N.V. Neuroptera and Raphidioptera in the Mordovia State Nature Reserve. Nat. Conserv. Res. 2017, 2, 38-46. [CrossRef]

39. Ruchin, A.B.; Khapugin, A.A. Red Data Book Invertebrates in a Protected Area of European Russia. Acta Zool. Acad. Sci. Hung. 2019, 65, 349-370. [CrossRef]

40. Tereshkin, I.S.; Tereshkina, L.V. Vegetation of the Mordovia Reserve. Successive series of the successions. Proc. Mordovia State Nat. Reserve 2006, 7, 186-287.

41. Khapugin, A.A.; Vargot, E.V.; Chugunov, G.G. Vegetation recovery in fire-damaged forests: A case study at the southern boundary of the taiga zone. For. Stud. 2016, 64, 39-50. [CrossRef]

42. Ruchin, A.B.; Egorov, L.V.; Khapugin, A.A.; Vikhrev, N.E.; Esin, M.N. The use of simple crown traps for the insects collection. Nat. Conserv. Res. 2020, 5, 87-108. [CrossRef]

43. Bouchard, P.; Bousquet, Y.; Davies, A.E.; Alonso-Zarazaga, M.A.; Lawrence, J.F.; Lyal, C.H.C.; Newton, A.F.; Reid, C.A.M.; Schmitt, M.; Ślipiński, S.A.; et al. Family-group names in Coleoptera (Insecta). ZooKeys 2011, 88, 1-972. [CrossRef]

44. Bouchard, P.; Bousquet, Y. Additions and corrections to "Family-group names in Coleoptera (Insecta)". ZooKeys 2020, 922, 65-139. [CrossRef]

45. Löbl, I.; Smetana, A. (Eds.) Catalogue of Palaearctic Coleoptera. Volume 7: Curculionoidea I; Apollo Books: Stenstrup, Denmark, 2011; p. 373.

46. Löbl, I.; Smetana, A. (Eds.) Catalogue of Palaearctic Coleoptera. Volume 8: Curculionoidea II; Apollo Books: Stenstrup, Denmark, 2013; p. 707.

47. Löbl, I.; Löbl, D. (Eds.) Catalogue of Palaearctic Coleoptera. Volume 2/1. Revised and Updated Version. Hy-Drophiloidea-Staphylinoidea; Brill: Leiden, The Netherlands; Boston, MA, USA, 2015; p. 1702.

48. Löbl, I.; Löbl, D. (Eds.) Catalogue of Palaearctic Coleoptera. Volume 3. Revised and Updated Version. Scara-Baeoidea-ScirtoideaDascilloidea-Buprestoidea-Byrrhoidea; Brill: Leiden, The Netherlands; Boston, MA, USA, 2016; p. 983.

49. Löbl, I.; Löbl, D. (Eds.) Catalogue of Palaearctic Coleoptera. Volume 1. Revised and Updated Version. Archostemata-Adephaga-Myxophaga; Brill: Leiden, The Netherlands; Boston, MA, USA, 2017; p. 1443.

50. Iwan, D.; Löbl, I. (Eds.) Catalogue of Palaearctic Coleoptera. Volume 5. Revised and Updated Second Edition. Tenebrionoidea; Brill: Leiden, The Netherlands; Boston, MA, USA, 2020; p. 945.

51. Danilevsky, M. (Ed.) Catalogue of Palaearctic Coleoptera. Volume 6/1. Updated and Revised Second Edition. Chrysomeloidea I (Vesperidae, Disteniidae, Cerambycidae); Brill: Leiden, The Netherlands; Boston, MA, USA, 2020; p. 712.

52. Robertson, J.; Ślipiński, A.; Moulton, M.; Shockley, F.W.; Giorgi, A.; Lord, N.P.; McKenna, D.D.; Tomaszewska, W.; Forrester, J.; Miller, K.B.; et al. Phylogeny and classification of Cucujoidea and the recognition of a new superfamily Coccinelloidea (Coleoptera: Cucujiformia). Syst. Entomol. 2015, 40, 745-778. [CrossRef]

53. Alonso-Zarazaga, M.A.; Barrios, H.; Borovec, R.; Bouchard, P.; Caldara, R.; Colonnelli, E.; Gültekin, L.; Hlaváč, P.; Koro-tyaev, B.; Lyal, C.H.C.; et al. Cooperative Catalogue of Palaearctic Coleoptera Curculionoidea. Monografías Electrónicas SEA 2017, 8, 1-729.

54. Löbl, I.; Smetana, A. (Eds.) Catalogue of Palaearctic Coleoptera. Volume 4. Elateroi-dea-Derodontoidea-Bos-trichoidea-LymexyloideaCleroidea-Cucujoidea; Apollo Books: Stenstrup, Denmark, 2007; p. 935.

55. Löbl, I.; Smetana, A. (Eds.) Catalogue of Palaearctic Coleoptera. Volume 6: Chrysomeloidae; Apollo Books: Stenstrup, Denmark, 2010; p. 924.

56. Bousquet, Y. Litteratura Coleopterologica (1758-1900): A guide to selected books related to the taxonomy of Coleoptera with publication dates and notes. ZooKeys 2016, 583, 1-776. [CrossRef]

57. Lachat, T.; Wermelinger, B.; Gossner, M.M.; Bussler, H.; Isacsson, G.; Müller, J. Saproxylic beetles as indicator species for dead-wood amount and temperature in European beech forests. Ecol. Indic. 2012, 23, 323-331. [CrossRef]

58. Carpaneto, G.M.; Baviera, C.; Biscaccianti, A.B.; Brandmayr, P.; Mazzei, A.; Mason, F.; Battistoni, A.; Teofili, C.; Rondinini, C.; Fattorini, S.; et al. A red list of Italian saproxylic beetles: Taxonomic overview, ecological features and conservation issues (Coleoptera). Fragm. Entomol. 2015, 47, 53-126. [CrossRef]

59. Gutowski, J.M.; Sućko, K.; Borowski, J.; Kubisz, D.; Mazur, M.A.; Melke, A.; Mokrzycki, T.; Plewa, R.; Żmihorski, M. Post-fire beetle succession in a biodiversity hotspot: Białowieża Primeval Forest. For. Ecol. Manag. 2020, 461, 117893. [CrossRef] 
60. Shannon, C.E. A mathematical theory of communication. Bell Syst. Tech. J. 1948, 27, 379-423. [CrossRef]

61. Magurran, A.E. Ecological Diversity and Its Measurement; Chapman \& Hall: London, UK, 1996; 179p.

62. Ruchin, A.B.; Egorov, L.V.; Khapugin, A.A. Usage of fermental traps for studying the species diversity of Coleoptera. Insects 2021, 12, 407. [CrossRef] [PubMed]

63. Ulyshen, M.D.; Hanula, J.L. A comparison of the beetle (Coleoptera) fauna captured at two heights above the ground in a North American temperate deciduous forest. Am. Midl. Nat. 2007, 158, 260-278. [CrossRef]

64. Tsinkevich, V.A. Checklist of Cucujoidea (Coleoptera) of Belarus (Eastern Europe). In Contributions to Systematics and Biology of Beetles. (Papers Celebrating the 80th Birthday of Igor Lopatin); Pensoft Publishers: Sofia, Bulgaria, 2005; pp. 333-345.

65. Tauzin, P. Ethologie et chorologie de Protaetia (Liocola) lugubris Herbst, 1786 sur le territoire français (Coleoptera, Cetoniidae, Cetoniinae, Cetoniini). Cetoniimania 2006, 3, 4-38.

66. Lassauce, A.; Anselle, P.; Lieutier, F.; Bouget, C. Coppice-with-standards with an overmature coppice component enhance saproxylic beetle biodiversity: A case study in French deciduous forests. For. Ecol. Manag. 2012, 266, 273-285. [CrossRef]

67. Lason, A.; Holly, M. Glischrochilus grandis Tournier, 1872-new species of beetle for the Polish fauna and new data on the occurrence of genus Glischrochilus Reitter, 1873 (Coleoptera: Nitidulidae: Cryptarchinae). Acta Entomol. Sil. 2015, 23, 1-4.

68. Urban, P.; Schulze, W. Ein aktueller Nachweis des Marmorierten Rosenkäfers Pro-taetia marmorata (Fabricius, 1792) in der Senne (Nordrhein-Westfalen) (Mitteilungen zur Insektenfauna Westfalens XXII). Mitteilungen der Arbeitsgemeinschaft Westfälischer Entomologen 2017, 33, 15-19.

69. Egorov, L.V.; Ruchin, A.B.; Semishin, G.B. Some data on the Coleoptera fauna of the Mordovia State Nature Reserve. Report 8. Proc. Mordovia State Nat. Reserve 2019, 22, 3-62.

70. Egorov, L.V.; Ruchin, A.B.; Semenov, V.B.; Semionenkov, O.I.; Semishin, G.B. Checklist of the Coleoptera of Mordovia State Nature Reserve, Russia. ZooKeys 2020, 962, 13-122. [CrossRef]

71. Ruchin, A.B.; Egorov, L.V.; Khapugin, A.A. Seasonal activity of Coleoptera attracted by fermental crown traps in forest ecosystems of Central Russia. Ecol. Quest. 2021, 32, 37-53.

72. Oude, J.E. Naamlijst van de glanskevers van Nederland en het omliggende gebied (Coleoptera: Nitidulidae and Brachypteridae). Ned. Faun. Meded. 1999, 8, 11-32.

73. Kurochkin, A.S. Fauna and bionomy of sap beetles (Coleoptera, Nitidulidae) and kateretid beetles (Coleoptera, Kateretidae) of Krasnosamarskoe forestry farm (Samara Region, Russia). Vestn. Samara Univ. Nat. Sci. 2007, 8, 120-128.

74. Nikitsky, N.B.; Mamontov, S.N.; Vlasenko, A.S. New data of beetles from Tula abatis forests (Coleoptera: Nitidulidae-Scolytidae) collected in window traps. Bull. Mosc. Soc. Nat. Biol. Ser. 2016, 121, 25-37.

75. Nikitsky, N.B.; Osipov, I.N.; Chemeris, M.V.; Semenov, V.B.; Gusakov, A.A. The beetles of the Prioksko-Terrasny Biosphere Reserve-Xylobiontes, Mycetobiontes and Scarabaeidae. Arch. Zool. Mus. Mosc. State Univ. 1996, 36, 1-197.

76. Oleksa, A.; Chybicki, I.J.; Gawronski, R.; Svensson, G.P.; Burczyk, J. Isolation by distance in saproxylic beetles may increase with niche specialization. J. Insect Conserv. 2013, 17, 219-233. [CrossRef]

77. Salnitska, M.; Solodovnikov, A. Rove beetles of the genus Quedius (Coleoptera, Staph-ylinidae) of Russia: A key to species and annotated catalogue. ZooKeys 2019, 847, 1-100. [CrossRef] [PubMed]

78. Bieńko, W.; Kirpsza, I.; Mokrzycki, T. New localities of Quedius dilatatus (Fabricius, 1787) (Coleoptera: Staphylinidae) in Poland and remarks on its biology. Wiad. Entomol. 2017, 36, 137-144.

79. Menocal, O.; Kendra, P.E.; Montgomery, W.S.; Crane, J.H.; Carrillo, D. Vertical distribution and daily flight periodicity of ambrosia beetles (Coleoptera: Curculionidae) in Florida avocado orchards affected by laurel wilt. J. Econ. Entomol. 2018, 111, 1190-1196. [CrossRef] [PubMed]

80. Sheehan, T.N.; Ulyshen, M.D.; Horn, S.; Hoebeke, E.R. Vertical and horizontal distribution of bark and woodboring beetles by feeding guild: Is there an optimal trap location for detection? J. Pest Sci. 2019, 92, 327-341. [CrossRef]

81. Ulyshen, M.D.; Sheehan, T.N. Trap height considerations for detection two economically important forest beetle guilds in southeastern US forests. J. Pest Sci. 2019, 92, 253-265. [CrossRef]

82. Holuša, J.; Fiala, T.; Foit, J. Ambrosia beetles prefer closed canopies: A case study in oak forests in Central Europe. Forests 2021, 12, 1223. [CrossRef]

83. Speight, M.C.D. Saproxylic invertebrates and their conservation. Council of Europe. Nat. Environ. Ser. 1989, 42, 1-79.

84. Haeler, E.; Bergamini, A.; Blaser, S.; Ginzler, C.; Hindenlang, K.; Keller, C.; Kiebacher, T.; Kormann, U.G.; Scheidegger, C.; Schmidt, R.; et al. Saproxylic species are linked to the amount and isolation of dead wood across spatial scales in a beech forest. Landsc. Ecol. 2021, 36, 89-104. [CrossRef]

85. Siitonen, J. Forest management, coarse woody debris and saproxylic organisms: Fennoscandian boreal forests as an example. Ecol. Bull. 2001, 49, 11-41.

86. Papis, M.; Mokrzycki, T. Saproxylic beetles (Coleoptera) of the strictly protected area Bukowa Góra in the Roztoczański National Park. For. Res. Pap. 2015, 76, 229-239. [CrossRef]

87. Seibold, S.; Bässler, C.; Baldrian, P.; Reinhard, L.; Thorn, S.; Ulyshen, M.D.; Weiß, I.; Müller, J. Dead-wood addition promotes non-saproxylic epigeal arthropods but effects are mediated by canopy openness. Biol. Conserv. 2016, 204, 181-188. [CrossRef]

88. Ekström, A.L.; Bergmark, P.; Hekkala, A.M. Can multifunctional forest landscapes sustain a high diversity of saproxylic beetles? For. Ecol. Manag. 2021, 490, 119107. [CrossRef] 
89. Löbel, S.; Snäll, T.; Rydin, H. Species richness patterns and metapopulation processes-Evidence from epiphyte communities in boreo-nemoral forests. Ecography 2006, 29, 169-182. [CrossRef]

90. Parisi, F.; Innangi, M.; Tognetti, R.; Lombardi, F.; Chirici, G.; Marchetti, M. Forest stand structure and coarse woody debris determine the biodiversity of beetle communities in Mediterranean mountain beech forests. Glob. Ecol. Conserv. 2021, $28, \mathrm{e} 01637$. [CrossRef]

91. Wermelinger, B.; Flückiger, P.F.; Obrist, M.K.; Duelli, P. Horizontal and vertical distribution of saproxylic beetles (Col., Buprestidae, Cerambycidae, Scolytinae) across sections of forest edges. J. Appl. Entomol. 2007, 131, 104-114. [CrossRef]

92. Zumr, V.; Remeš, J.; Pulkrab, K. How to Increase Biodiversity of Saproxylic Beetles in Commercial Stands through Integrated Forest Management in Central Europe. Forests 2021, 12, 814. [CrossRef]

93. Schroeder, B.; Buddle, C.; Saint-Germain, M. Activity of flying beetles (Coleoptera) at two heights in canopy gaps and intact forests in a hardwood forest in Quebec. Can. Entomol. 2009, 141, 515-520. [CrossRef]

94. Preisser, E.; Smith, D.C.; Lowman, M.D. Canopy and ground level insect distribution in a temperate forest. Selbyana 1998, 19, 141-146.

95. Gossner, M.M.; Struwe, J.-F.; Sturm, S.; Max, S.; McCutcheon, M.; Weisser, W.W.; Zytynska, S.E. Searching for the optimal sampling solution: Variation in invertebrate communities, sample condition and DNA quality. PLoS ONE 2016, 11, e0148247. [CrossRef]

96. Basset, Y. Influence of leaf traits on the spatial distribution of arboreal arthropods within an overstorey rainforest tree. Ecol. Entomol. 1992, 17, 8-16. [CrossRef]

97. Brown, J.; Vargo, S.; Connor, E.F.; Nuckols, M.S. Causes of vertical stratification in the density of Cameraria hamadryadella. Ecol. Entomol. 1997, 22, 16-25. [CrossRef]

98. Maguire, D.Y.; Robert, K.; Brochu, K.; Larrivée, M.; Buddle, C.M.; Wheeler, T.A. Vertical stratification of beetles (Coleoptera) and flies (Diptera) in temperate forest canopies. Environ. Entomol. 2014, 43, 9-17. [CrossRef] [PubMed]

99. Flaherty, L.; Gutowski, J.M.; Mayo, P.; Mokrzycki, T.; Pohl, G.; Silk, P.; Webster, R.; Hughes, C.; Van Rooyen, K.; Sweeney, J. Pheromone-enhanced lure blends and multiple trap heights improve detection of bark and wood-boring beetles potentially moved in solid wood packaging. J. Pest Sci. 2019, 92, 309-325. [CrossRef]

100. Allemand, R.; Aberlenc, H.P. Une methode efficace d'echantillonnage de l'entomofaune des frondaisons: Le piege attractif aerien. Bull. Soc. Entomol. Suisse 1991, 64, 293-305.

101. Brustel, H. Coleopteres Saproxyliques et Valeur Biologique des Forets Françaises. Perspectives Pour la Conservation du Patrimoine Naturel; Les Dossiers Forestiers 13; Office National des Forets: Paris, France, 2004; 297p.

102. Li, Y.; Meng, Q.; Silk, P.; Gao, W.; Mayo, P.; Sweeney, J. Effect of semiochemicals and trap height on catch of Neocerambyx raddei in Jilin province, China. Entomol. Exp. Appl. 2017, 164, 94-101. [CrossRef]

103. Heidrich, L.; Bae, S.; Levick, S.; Seibold, S.; Weisser, W.; Krzystek, P.; Magdon, P.; Nauss, T.; Schall, P.; Serebryanyk, A.; et al. Heterogeneity-diversity relationships differ between and within trophic levels in temperate forests. Nat. Ecol. Evol. 2020, 4 , 1204-1212. [CrossRef] [PubMed]

104. Carnicer, J.; Vives-Ingla, M.; Blanquer, L.; Méndez-Camps, X.; Rosell, C.; Sabaté, S.; Gutiérrez, E.; Sauras, T.; Peñuelas, J.; Barbeta, A. Forest resilience to global warming is strongly modulated by local-scale topo-graphic, microclimatic and biotic conditions. J. Ecol. 2021, 109, 3322-3339. [CrossRef]

105. Plewa, R.; Jaworski, T.; Hilszczański, J.; Horák, J. Investigating the biodiversity of the forest strata: The importance of vertical stratification to the activity and development of saproxylic beetles in managed temperate deciduous forests. For. Ecol. Manag. 2017, 402, 186-193. [CrossRef]

106. Seibold, S.; Hagge, J.; Müller, J.; Gruppe, A.; Brandl, R.; Bässler, C.; Thorn, S. Experiments with dead wood reveal the importance of dead branches in the canopy for saproxylic beetle conservation. For. Ecol. Manag. 2018, 409, 564-570. [CrossRef]

107. Shah, A.A.; Dillon, M.E.; Hotaling, S.; Woods, H.A. High elevation insect communities face shifting ecological and evolutionary landscapes. Curr. Opin. Insect Sci. 2020, 41, 1-6. [CrossRef]

108. Gaudio, N.; Gendre, X.; Saudreau, M.; Seigner, V.; Balandier, P. Impact of tree canopy on thermal and radiative microclimates in a mixed temperate forest: A new statistical method to analyse hourly temporal dynamics. Agric. For. Meteorol. 2017, 237-238, 71-79. [CrossRef]

109. De Lombaerde, E.; Blondeel, H.; Baeten, L.; Landuyt, D.; Perring, M.P.; Depauw, L.; Maes, S.L.; Wang, B.; Verheyen, K. Light, temperature and understorey cover predominantly affect early life stages of tree seedlings in a multifactorial mesocosm experiment. For. Ecol. Manag. 2020, 461, 117907. [CrossRef]

110. Thom, D.; Sommerfeld, A.; Sebald, J.; Hagge, J.; Müller, J.; Seidl, R. Effects of disturbance patterns and deadwood on the microclimate in European beech forests. Agric. For. Meteorol. 2020, 291, 108066. [CrossRef]

111. Woods, H.A.; Saudreau, M.; Pincebourde, S. Structure is more important than physiology for estimating intracanopy distributions of leaf temperatures. Ecol. Evol. 2018, 8, 5206-5218. [CrossRef]

112. Blonder, B.; Escobar, S.; Kapás, R.E.; Michaletz, S.T. Low predictability of energy balance traits and leaf temperature metrics in desert, montane and alpine plant communities. Funct. Ecol. 2020, 34, 1882-1897. [CrossRef]

113. Miller, B.D.; Carter, K.R.; Reed, S.C.; Wood, T.E.; Cavaleri, M.A. Only sun-lit leaves of the uppermost canopy exceed both air temperature and photosynthetic thermal optima in a wet tropical forest. Agric. For. Meteorol. 2021, 301, 108347. [CrossRef] 
114. Ulyshen, M.D. Arthropod vertical stratification in temperate deciduous forests: Implications for conservation-oriented management. For. Ecol. Manag. 2011, 261, 1479-1489. [CrossRef]

115. Neves, F.S.; Silva, J.O.; Espírito-Santo, M.M.; Fernandes, G.W. Insect Herbivores and Leaf Damage along Successional and Vertical Gradients in a Tropical Dry Forest. Biotropica 2014, 46, 14-24. [CrossRef]

116. Wardhaugh, C.W. The spatial and temporal distributions of arthropods in forest canopies: Uniting disparate patterns with hypotheses for specialisation. Biol. Rev. 2014, 89, 1021-1041. [CrossRef] [PubMed]

117. De Frenne, P.; Zellweger, F.; Rodríguez-Sánchez, F.; Scheffers, B.R.; Hylander, K.; Luoto, M. Global buffering of temperatures under forest canopies. Nat. Ecol. Evol. 2019, 3, 744-749. [CrossRef] [PubMed]

118. Zellweger, F.; Coomes, D.; Lenoir, J.; Depauw, L.; Maes, S.L.; Wulf, M.; Kirby, K.J.; Brunet, J.; Kopecký, M.; Máliš, F.; et al. Seasonal drivers of understorey temperature buffering in temperate deciduous forests across Europe. Glob. Ecol. Biogeogr. 2019, 28, 1774-1786. [CrossRef] [PubMed]

119. Prévosto, B.; Helluy, M.; Gavinet, J.; Fernandez, C.; Balandier, P. Microclimate in Mediterranean pine forests: What is the influence of the shrub layer? Agric. For. Meteorol. 2020, 282-283, 107856. [CrossRef]

120. Landuyt, D.; De Lombaerde, E.; Perring, M.P.; Hertzog, L.R.; Ampoorter, E.; Maes, S.L.; De Frenne, P.; Ma, S.; Proesmans, W.; Blondeel, H.; et al. The functional role of temperate forest understorey vegetation in a changing world. Glob. Chang. Biol. 2019, 25, 3625-3641. [CrossRef]

121. Kovács, B.; Tinya, F.; Ódor, P. Stand structural drivers of microclimate in mature temperate mixed forests. Agric. For. Meteorol. 2017, 234-235, 11-21. [CrossRef]

122. Jonsell, M.; Hansson, J. Logs and stumps in clearcuts support similar saproxylic beetle diversity: Implications for bioenergy harvest. Silva Fenn. 2011, 45, 1053-1064. [CrossRef]

123. Pakeman, R.J.; Stockan, J.A. Drivers of carabid functional diversity: Abiotic environment, plant functional traits, or plant functional diversity? Ecology 2014, 95, 1213-1224. [CrossRef]

124. Penone, C.; Allan, E.; Soliveres, S.; Felipe-Lucia, M.R.; Gossner, M.M.; Seibold, S.; Simons, N.K.; Schall, P.; Van Der Plas, F.; Manning, P.; et al. Specialisation and diversity of multiple trophic groups are promoted by different forest features. Ecol. Lett. 2019, 22, 170-180. [CrossRef]

125. Schneider, A.; Blick, T.; Köhler, F.; Pauls, S.U.; Römbke, J.; Zub, P.; Dorow, W.H.O. Animal diversity in beech forests-An analysis of 30 years of intense faunistic research in Hessian strict forest reserves. For. Ecol. Manag. 2021, 499, 119564. [CrossRef]

126. Tinya, F.; Kovács, B.; Bidló, A.; Dima, B.; Király, I.; Kutszegi, G.; Lakatos, F.; Mag, Z.; Márialigeti, S.; Nascimbene, J.; et al. Environmental drivers of forest biodiversity in temperate mixed forests-A multi-taxon approach. Sci. Total Environ. 2021, 795, 148720. [CrossRef] [PubMed]

127. Vincent, A.; Tillier, P.; Vincent-Barbaroux, C.; Bouget, C.; Sallé, A. Influence of forest decline on the abundance and diversity of Raphidioptera and Mecoptera species dwelling in oak canopies. Eur. J. Entomol. 2020, 117, 372-379. [CrossRef]

128. Martínez-Pérez, S.; Borja, R.; García-París, M.; Galante, E.; Micó, E. Ensambles de dermápteros (Dermaptera, Forficulidae) en microhábitats saproxílicos de bosques ibéricos de quercíneas. Bol. Asoc. Esp. Entomol. 2021, 45, 73-84. 